Environmental Science

Sunil Nautiyal

Ruediger Schaldach

K.V. Raju

Harald Kaechele

Bill Pritchard

Kottapalli Sreenivasa Rao Editors

Climate Change

Challenge (3C) and

Social-Economic-

Ecological

Interface-Building

Exploring Potential Adaptation

Strategies for Bio-resource Conservation

and Livelihood Development

을 Springer 


\title{
Socio-economic and Agricultural Vulnerability Across Districts of Karnataka
}

\author{
K.V. Raju, R.S. Deshpande and B. Satyasiba
}

\begin{abstract}
Vulnerability assessments can play a vital role in the design of appropriate adaptation and mitigation policies targeted towards climate change and its impacts on ecosystems, and those who depend upon these resources for their livelihoods and well-being. Vulnerability is often reflected in the state of the economic system as well as the socio-economic features of the population living in that system. The current paper attempts to build a picture of the socio-economic context of vulnerability by focusing on indicators that measure both the state of development of the people as well as its capacity to progress further. The result of agricultural vulnerability index suggests indicators like cropping intensity, gross irrigated area and commercial crop area that are the major drivers in determining the vulnerability of districts of Karnataka. The socio-economic index depicts indicators like per capita income, population density and percentage of literacy rate that are the major drivers and contribute to the overall livelihood vulnerability of districts.
\end{abstract}

Keywords Climate change - Vulnerability index - Principal component analysis • Agricultural vulnerability $\cdot$ Socio-economic vulnerability $\cdot$ Karnataka $\cdot$ India

This paper was submitted to the International Conference on Climate Change and Social-Ecological-Economical Interface-Building: Modeling Approach to Exploring Potential Adaptation Strategies for Bioresource Conservation and Livelihood Development held on May 20-21, 2015, at Institute for Social and Economic Change, Bangalore, India.

\footnotetext{
K.V. Raju ( $\square)$

ICRISAT Development Center, International Crop Research

Institute for the Semi-Arid Tropics, Patancheru, Telangana, India

e-mail: kv.raju@cgiar.org
}

R.S. Deshpande

ICSSR, Bangalore, India

e-mail: rs.kalbandi@gmail.com

B. Satyasiba

CEENR, ISEC, Bangalore, India 


\section{Introduction}

Vulnerability to natural hazards varies widely across communities, sectors and regions. The socio-economic vulnerability is determined by the internal structure of any social system that decides sensitivity of societies and communities to the incidence of hazards. The internal structure also helps to cope with damages from external shocks. It poses the important research question as to why there are different levels of vulnerability within a particular society, even in the context of similar hazards. The possible answer may be that the individuals and groups differ in terms of equality, entitlement capacity, institutions, political and cultural aspects that are responsible factors for the differential vulnerability. For example, marginalized communities are forced to live in susceptible regions that exposes them to floods/droughts and different diseases as compared to other people.

\section{Vulnerability}

A growing body of literature over the past two decades has identified climate change as the prime issue to global environmental degradation, and has analyzed the associated vulnerability and biodiversity loss (IPCC 2007). According to Fussel (2007), climate related vulnerability assessments are based on the characteristics of the vulnerable system spanning over physical, economic and social factors. The Intergovernmental Panel on Climate Change (IPCC), in its Second Assessment Report (IPCC 1996), defines vulnerability as "the extent to which climate change may damage or harm a system." It adds that vulnerability "depends not only on a system's sensitivity, but also on its ability to adapt to new climatic conditions"; and vulnerability depends on the level of economic development and institutions. Watson et al. (1996) argued that socio-economic systems "typically are more vulnerable in developing countries where economic and institutional circumstances are less favourable". In addition, social scientists tend to view vulnerability as representing the set of socio-economic factors that determine people's ability to cope with stress or change (Allen 2003) while climate scientists often view vulnerability in terms of the likelihood of occurrence and impacts of weather and climate related events (Nicholls et al. 1999).

IPCC defines vulnerability in terms of systems as "the degree to which a system is susceptible to, or unable to cope with, adverse effects of climate change, including climate variability and extremes" (IPCC 2007). Vulnerability is a function of the character, magnitude and rate of climate variation to which a system is exposed, its sensitivity and its adaptive capacity (IPCC 2007).

It is well understood that poor people in the poorest countries are the most vulnerable to the impacts of anthropogenic climate change (Stern et al. 2006). The poor are adversely impacted by climate change because they live in heavily impacted countries and locations within those countries; depend on natural 
resource-based livelihoods that are disproportionately affected by climate change; and have the weakest ability to adapt to the impacts. Small and marginal farmers are more vulnerable to both the current and future climate change impacts given their high dependence on agriculture, strong reliance on ecosystem and rapid population growth.

Vulnerability assessments can play a vital role in the design of appropriate adaptation and mitigation policies targeted towards climate change and its impacts on ecosystems, and those who depend upon these resources for their livelihoods and well-being. Every human community in the globe has a tendency to become adversely affected by the changes in climate, regardless of the communities' contribution to that change. This tendency is simply known as vulnerability of that particular community to climate change impacts. Agricultural and social vulnerability explicitly focuses on those agricultural, demographic and socio-economic factors that increase or attenuate the impacts of hazard events on local populations.

People who live in arid or semi-arid regions, in low-lying coastal areas, in water limited or flood-prone areas, or on small islands are particularly vulnerable to climate change (Watson et al. 1996). It is clear that climate change will, in many parts of the world, adversely affect socio-economic sectors, including water resources, agriculture, forestry, fisheries and human settlements, ecological systems and human health with developing countries being the most vulnerable (IPCC 2001). Developing countries have lesser capacity to adapt and are more vulnerable to climate change damages, just as they are to other stresses. This condition is most extreme among the poorest people (IPCC 2001).

There is an increasing need to develop indicators of vulnerability and of adaptive capacity both to determine the robustness of response strategies over time and to understand better the underlying processes (Adger et al. 2004). At the district level, vulnerability assessments contribute to setting development priorities and monitoring progress. Sectoral assessments provide details and targets for strategic development plans. In Karnataka, agricultural farmers and agricultural labourers form $56 \%$ of the total workforce (Government of Karnataka 2005) and this is considered as one of the driving forces in determining the socio-economic vulnerabilities of communities in Karnataka. In the present context, a district-wise socio-economic and agricultural vulnerability profile of Karnataka was developed.

\section{Objectives, Method and Data}

The key objectives of this assessment are: (a) To assess vulnerability of agricultural sector across the districts of Karnataka; (b) To estimate the socio-economic vulnerability of the districts of Karnataka.

The data pertaining to various socio-economic and agricultural indicators were collected and compiled from different sources such as Census of India (2011) and Statistical Abstracts of Karnataka (Directorate of Economics and Statistics), 200809, 2009-10 and 2010-11. To understand the agricultural and socio-economic 
profile, the study analyses important indicators across the districts of Karnataka. This has been done by consultation with experts and based on previous studies (Table 1).

Vulnerability to climate change is a comprehensive process affected by a large number of indicators. However, it is not possible to consider all the available indicators, so only the most significant and representative indicators relevant to Karnataka state were selected in the development of vulnerability indices. Indicators considered in this study are

- Agricultural indicators: Net sown area (3 years average), cropping intensity, area under commercial crops to the total cropped area (TCA), percentage irrigated area to TCA (3 years average), number of tractors/1000 ha area sown, total fallow land (3 years average) and agricultural credit cooperative societies/lakh population.

- Socio-economic indicators: Population density, percentage population of scheduled caste (SC) and scheduled tribe (ST), literacy rate, percentage of marginal landholder $(<1 \mathrm{ha})$, percentage of non-workers, livestock units per lakh population, per capita income (3 years average), cropping intensity and percentage irrigated area to TCA (3 years average).

\section{Agricultural Vulnerability Index}

\subsection{Net Sown Area}

Agricultural activities play a dominant role in shaping the livelihood across the districts of Karnataka. Net sown area is an important indicator of agricultural development in a district. The net sown area refers to the particular area sown once during an agriculture year. In the present study we have incorporated a 3-year average of the net sown area. Districts from northern Karnataka have more net sown area than the southern districts of Karnataka. The districts of Gulbarga and Gadag have the highest net sown area of 87.04 and $83.26 \%$, respectively. The districts of Uttara Kannada and Shimoga have the least net sown area of 11.04 and $26.21 \%$, respectively. Figure 1 presents district-wise percentage of net sown area to the total geographical area districts with high net sown area are above the median value and districts with low net sown area are below the median value.

\subsection{Commercial Crops}

Commercial crops are high value crops which are of crucial importance to the economy of a district. It was observed that in Karnataka state, over the years, cultivation of commercial crops has increased. The economic value for commercial 
Table 1 Indicators used in earlier vulnerability studies

\begin{tabular}{|c|c|c|}
\hline Study/Author(s) & Major indicators used & $\begin{array}{l}\text { Indicators used in the present } \\
\text { study }\end{array}$ \\
\hline $\begin{array}{l}\text { Vulnerability to agricultural } \\
\text { drought in Western Orissa: A } \\
\text { case study of representative } \\
\text { blocks (Swain and Swain } \\
\text { 2011) }\end{array}$ & $\begin{array}{l}\text { Socio-economic indicators } \\
\text { used: irrigation, crops, } \\
\text { marginal farmers, land use } \\
\text { pattern, literacy rate, } \\
\text { population density, } \\
\text { institutional factors, forest } \\
\text { area, total geographic area, } \\
\text { barren and other fallow land }\end{array}$ & $\begin{array}{l}\text { Irrigation, marginal farmers, } \\
\text { literacy rate, population } \\
\text { density, fallow land }\end{array}$ \\
\hline $\begin{array}{l}\text { Analysis of vulnerability } \\
\text { indices in various } \\
\text { agro-climatic zones of Gujarat } \\
\text { (Hiremath and Shiyani 2013) }\end{array}$ & $\begin{array}{l}\text { Density of population, } \\
\text { literacy rate, cropping } \\
\text { intensity, irrigation, forest } \\
\text { area, food crop, non-food } \\
\text { crop, net sown areas, } \\
\text { livestock population, main } \\
\text { workers, cultivators, marginal } \\
\text { workers, non-workers }\end{array}$ & $\begin{array}{l}\text { Density of population, } \\
\text { literacy rate, cropping } \\
\text { intensity, irrigation, net sown } \\
\text { areas, livestock population, } \\
\text { non-workers }\end{array}$ \\
\hline $\begin{array}{l}\text { A simple human vulnerability } \\
\text { index to climate change } \\
\text { hazards for Pakistan (Khan } \\
\text { and Salman 2012) }\end{array}$ & $\begin{array}{l}\text { Density of population, } \\
\text { literacy, sanitation, electricity, } \\
\text { livestock }\end{array}$ & $\begin{array}{l}\text { Density of population, } \\
\text { literacy, livestock population }\end{array}$ \\
\hline $\begin{array}{l}\text { Environmental benefits and } \\
\text { vulnerability reduction } \\
\text { through Mahatma Gandhi } \\
\text { National Rural Employment } \\
\text { Guarantee Scheme (IISc } \\
\text { 2013) }\end{array}$ & $\begin{array}{l}\text { Groundwater depth, cropping } \\
\text { intensity, irrigation intensity, } \\
\text { net area irrigated, number of } \\
\text { days of irrigation water } \\
\text { availability, area under food } \\
\text { grain production, crop yields, } \\
\text { livestock population, soil } \\
\text { organic carbon and soil } \\
\text { erosion, migration, wage } \\
\text { rates, percentage change in } \\
\text { the number of days of } \\
\text { employment, livestock } \\
\text { population }\end{array}$ & $\begin{array}{l}\text { Cropping intensity, irrigation, } \\
\text { livestock population }\end{array}$ \\
\hline $\begin{array}{l}\text { Climate change impact on } \\
\text { livelihood, vulnerability and } \\
\text { coping mechanisms: a case } \\
\text { study of West Arid Zone, } \\
\text { Ethiopia (Senbeta 2009) }\end{array}$ & $\begin{array}{l}\text { Land size, livestock number, } \\
\text { literacy, sex, gender and age }\end{array}$ & Livestock number, literacy \\
\hline $\begin{array}{l}\text { Quantitative assessment of } \\
\text { vulnerability to climate } \\
\text { change (ICRISAT 2009) } \\
\text { (http://www.icrisat.org/what- } \\
\text { we-do/impi/training-cc/ } \\
\text { october-2-3-2009/ } \\
\text { vulnerability-analysis- } \\
\text { manual.pdf, accessed in Aug } \\
\text { 2013) }\end{array}$ & $\begin{array}{l}\text { Cropping intensity, irrigation } \\
\text { area, total food grains (tons) } \\
\text { net sown area, literacy rate, } \\
\text { density of population, } \\
\text { livestock, population, total } \\
\text { food crops area, total no food } \\
\text { crops area, life expectancy }\end{array}$ & $\begin{array}{l}\text { Cropping intensity, irrigation } \\
\text { area, net sown area, literacy } \\
\text { rate, density of population, } \\
\text { livestock population }\end{array}$ \\
\hline
\end{tabular}




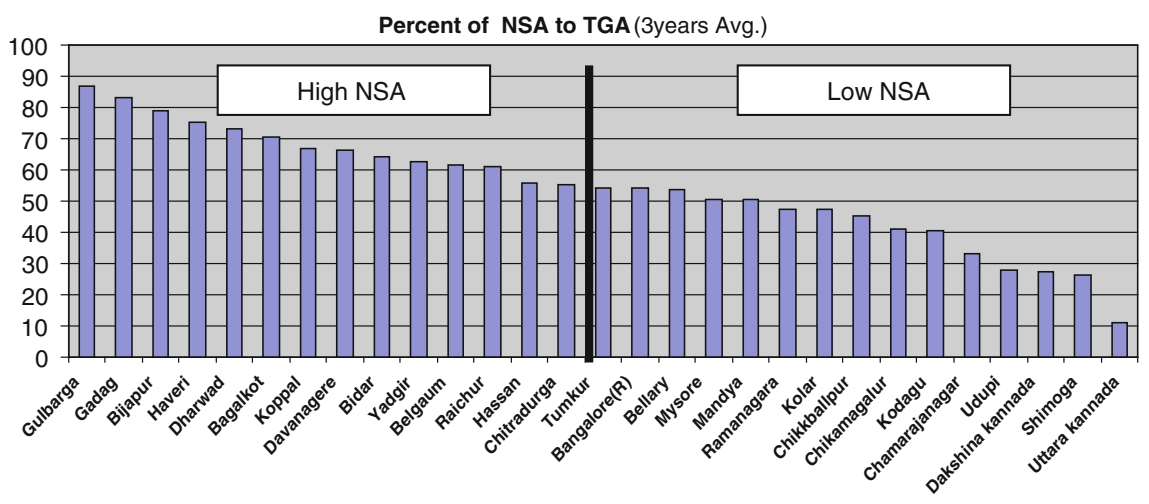

Fig. 1 Percentage net sown area of (NSA) to the total geographical area (3 years average) in districts of Karnataka (based on Directorate of Economics and Statistics, Ministry of Agriculture, 2008-09, 2009-2010)

crops has encouraged farmers to grow them. The major commercial crops are sugarcane and cotton among others. The northern districts have been observed to perform better in terms of commercial crops as compared to the southern regions of Karnataka (Fig. 2). This may be due to the fact that quality of land in central and northern regions of Karnataka is more suitable for cotton and sugarcane cultivation. The districts of Belgaum and Haveri ranked first and second in the state in terms of area under commercial crops to TCA, with 24.91 and $24.90 \%$, respectively. Likewise, Mysore, Dharwad and Bagalkot districts also have a considerable percentage of area under commercial crops. The districts of Dakshin Kannada and Bangalore Rural have the least percentage of area under commercial crops. Figure 2

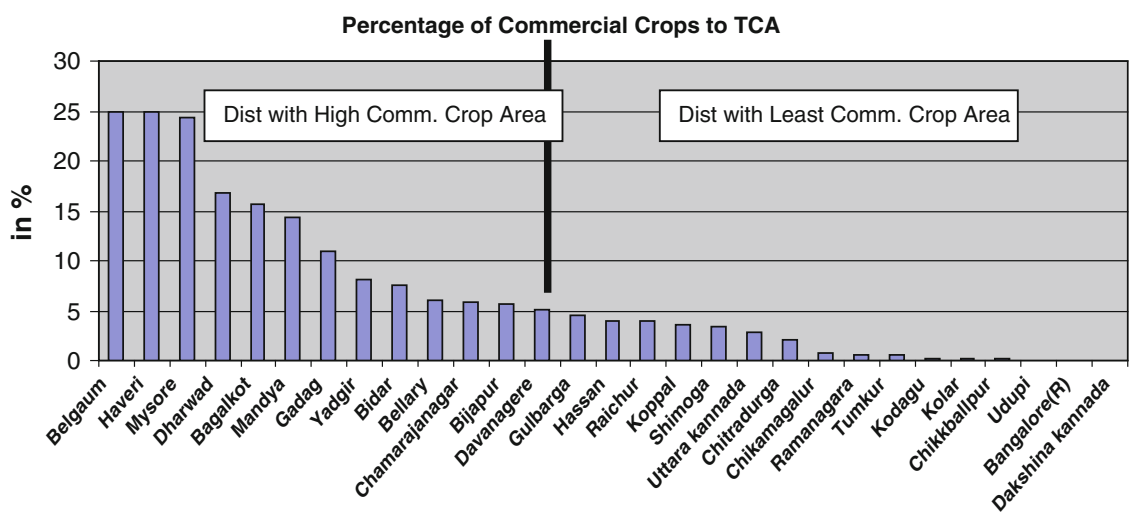

Fig. 2 Percentage area under commercial crops to the total cropped area (3 years average) in districts of Karnataka (based on Directorate of Economics and Statistics, Ministry of Agriculture (2008-09, 2009-10) 


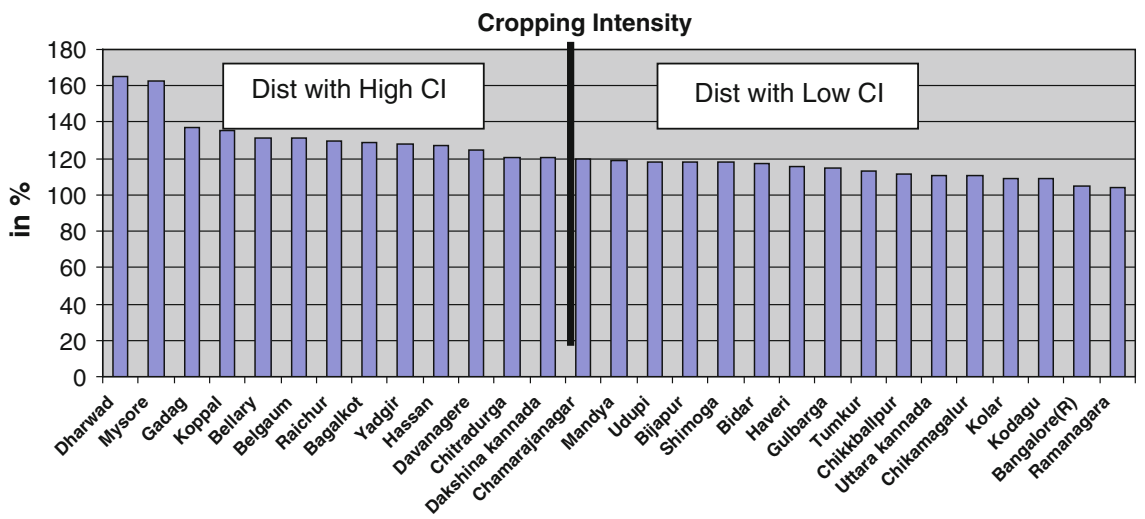

Fig. 3 Cropping intensity $(C I)$ across the districts of Karnataka (based on Directorate of Economics and Statistics, Ministry of Agriculture, 2010-11)

presents the percentage of area under commercial crops to TCA across the districts of Karnataka (Fig. 3).

\subsection{Cropping Intensity}

Cropping intensity refers to cultivation of more than one crop in the same field during the same agricultural year. Higher the cropping intensity essentially means more number of crops cultivated in a year. Normally, districts with more irrigation water availability have higher cropping intensities. In addition, mechanization of farmlands has also had considerable effects on increasing cropping intensities. Dharwad district was observed to have the highest cropping intensity of $164.74 \%$ followed by Mysore with $162.33 \%$. Districts like Bellary, Raichur and Koppal were also found to have good cropping intensities. The government has encouraged farmers to adopt water conservation methods and has focused on developing irrigation provisioning facilities in these regions thereby leading to increased cropping intensities in these districts.

\subsection{Gross Irrigated Area}

Irrigation water availability is essential for climate resilient agricultural production. In Karnataka, a large portion of area is under rainfed agriculture. Karnataka is one of the states with less irrigated area in the country, i.e. $32 \%$ of gross irrigated area to TCA (Ministry of Agriculture, GoI, 2010-11). Among the different districts, Shimoga has the highest area of about $62 \%$ of its TCA under irrigation and the 


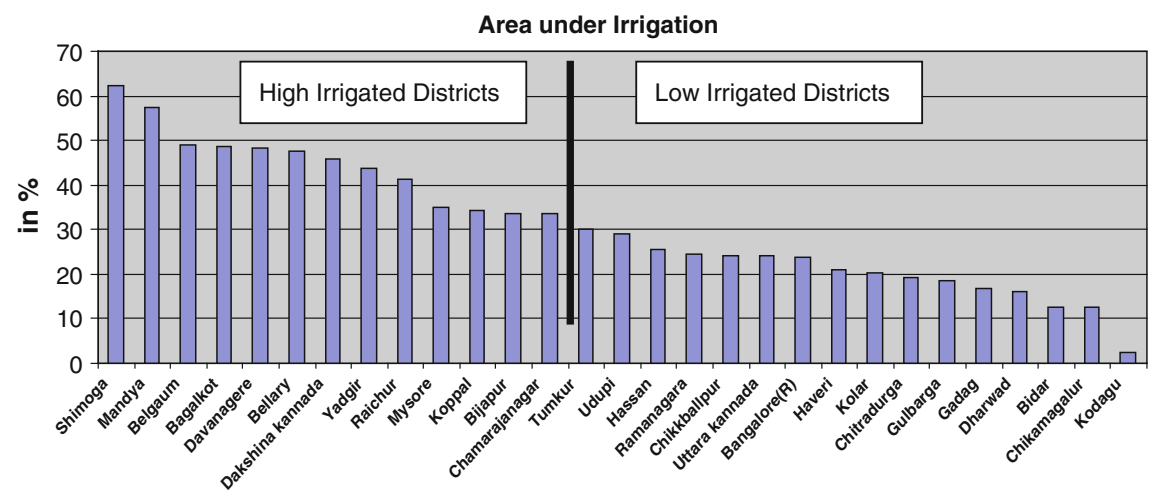

Fig. 4 Gross irrigated area as a percentage of total cropped area (3 years average) in districts of Karnataka (based on Directorate of Economics and Statistics, Ministry of Agriculture, 2008-09, 2009-10)

least in the state is in Kodagu district (2.34 \%). In the northern region of Karnataka, Belgaum district has $48.9 \%$ of TCA under irrigation and in southern Karnataka, the district of Mandya has $57.52 \%$ area under irrigation, which is the second highest in the state. The districts of northern Karnataka namely Bagalkot, Bellary, Yadgiri, Raichur, Koppal and Bijapur have significant area under irrigation after Belgaum. Bidar district has the least area under irrigation in the northern region $(12.77 \%)$. The existing major reservoirs in the northern regions have the potential to bring additional area under irrigation. Figure 4 presents the percentage of irrigated area to TCA across the districts of Karnataka.

\subsection{Fallow Land}

Agricultural development is dependent on proper utilization of available land resources. Fallow land refers to the cultivable area which has not been cultivated for a period of time. The districts, where large areas have been left fallow, can be considered as districts where there is underutilization of land resources. Raichur has the highest percentage of fallow land to its total geographical area. It has about $26.46 \%$ of its geographical area under fallow land, followed by Yadgiri with $17.04 \%$ of area under fallow land. The districts of Uttara Kannada and Kodagu have only 1.89 and $2.08 \%$ of area under fallow land, respectively, the least in the state. In northern Karnataka, the districts of Haveri and Gadag also have less area under fallow land, about 3.37 and $4.16 \%$, respectively. Figure 5 depicts the average percentage of area under fallow land over 3 years across the districts of Karnataka. 


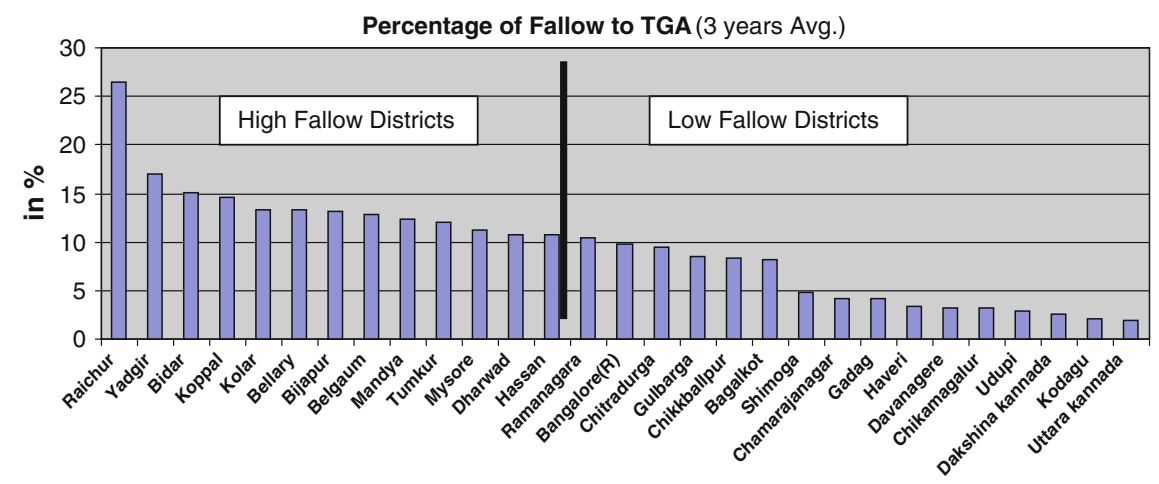

Fig. 5 Average percentage of fallow land to total geographical area (3 years average) across districts of Karnataka (based on Directorate of Economics and Statistics, Ministry of Agriculture, 2008-09, 2009-10)

\subsection{Agricultural Credit Cooperative Societies}

The role of institutions providing financial support to farmers is extremely important for sustainable agricultural production, as it ensures supply of agricultural credit and funds during the different stages of crop production and has the potential to deliver goods and services. Agricultural finance is a critical factor that impacts the development of agricultural activities in the state. The agricultural cooperative societies are considered, as the grass root financial institutions for the farming communities and provide credit to cultivars in time. At the state level, Belgaum district has the highest number of agricultural cooperative societies/lakh population, where it has 16 cooperatives. Likewise in southern Karnataka, Mandya district also has many cooperative societies per lakh population - about 13 agricultural cooperatives. The districts of Udupi and Dakshin Kannada have only 4 and 5 cooperatives per lakh population, respectively, which is the least in the state. Figure 6 represents the number of agricultural credit cooperative societies per lakh population across the districts of Karnataka.

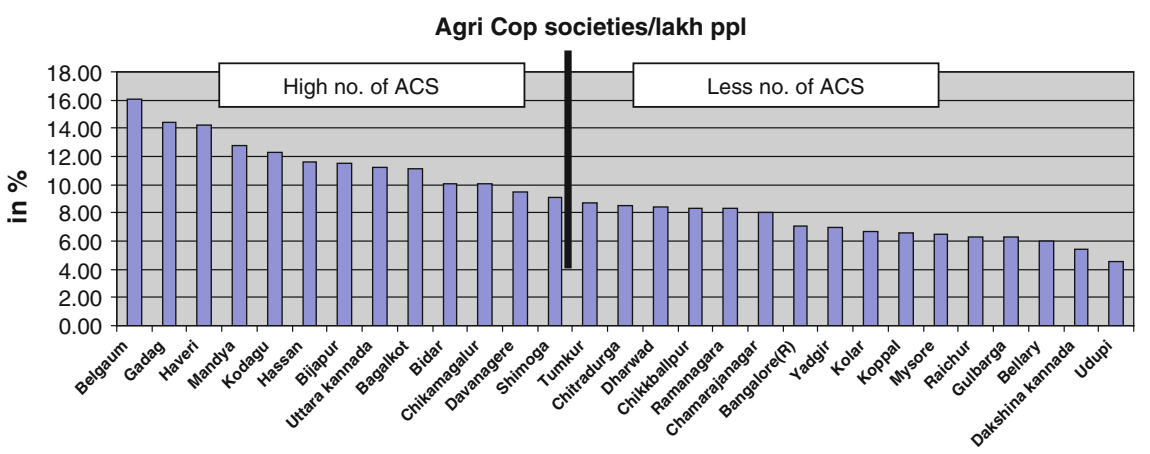

Fig. 6 Agricultural cooperative societies (ACS) (no. lakh population) in various districts of Karnataka (based on the Department of Co-operation cited in DES, 2010-11) 


\section{Socio-economic Vulnerability Index}

\subsection{Population Density}

Higher the population density, higher will be the dependency on finite resources. Further, higher density of population could also potentially trigger environmental and health problems (Hiremath and Shiyani 2013). The density of population in Mysore district is highest among all the districts in the state (476 persons $/ \mathrm{km}^{2}$ ). The lowest population density in the state of about 135 persons $/ \mathrm{km}^{2}$ is in Kodagu district. In the northern districts, the main reason for migration is severe drought occurrence for consecutive years. Figure 7 gives the details of population density across the districts of Karnataka.

\subsection{SC and ST Population}

The social class of SC and ST are considered as the deprived section of the society (Karade 2008). The districts in southern Karnataka like Kolar, Chikkaballapura, Chamrajnagar and Chitradurg have the highest percentage of this category. Kolar has the highest of $30.32 \%$ SC population in the state, followed by Chamrajnagar with $25.42 \%$. The population of SC is more in southern districts of Karnataka compared to the northern districts. In northern region of Karnataka, Raichur has $19.03 \%$ of ST population, highest in the state, followed by Bellary district. The ST population in the southern Karnataka district of Chitradurg also constitutes a large percentage $(18.23 \%)$, while other districts like Chikkaballapura, Davengere and

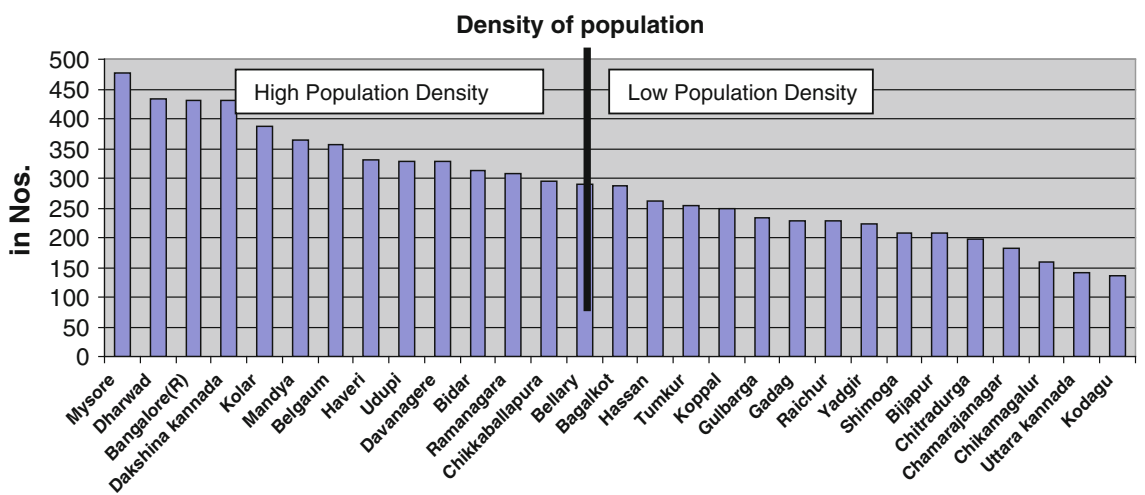

Fig. 7 Population density in different districts of Karnataka (based on Census of India, 2011) (Note Bangalore Urban is not included here as it is an outlier) 


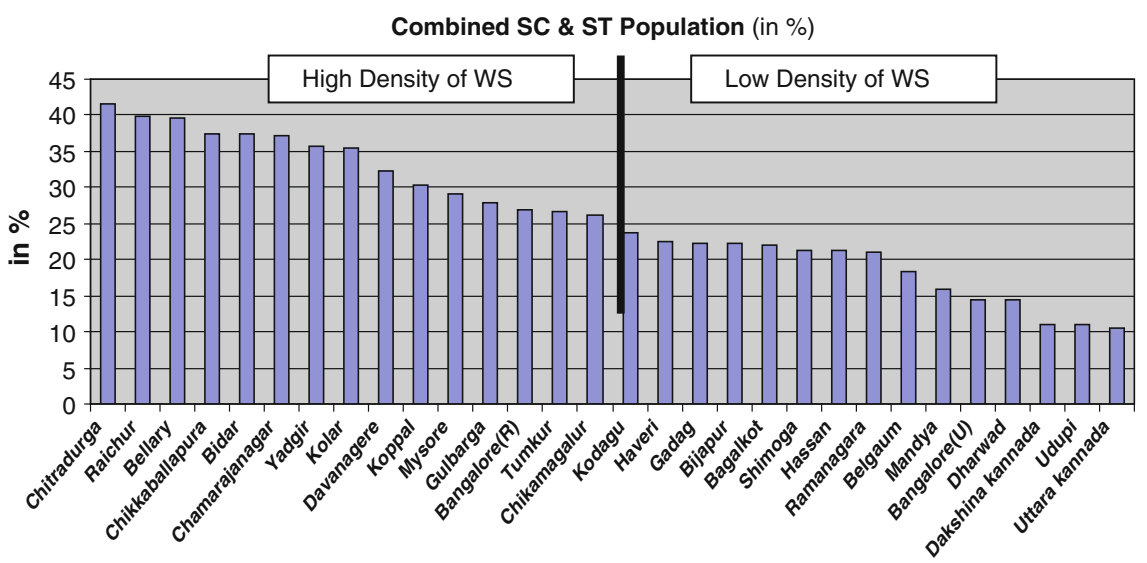

Fig. 8 Percentage of total scheduled caste $(S C)$ and scheduled tribe $(S T)$ population in the districts of Karnataka (based on Census of India, 2011)

Chamrajnagar and Kodagu too have high percentage of ST population. Total of SC and ST is highest in Chitradurg district while the percentage is lowest in Uttara Kannada (Fig. 8).

\subsection{Literacy Rate}

Higher literacy rates could enable communities to diversify their employment and income sources, enhancing standards of living and increasing their resilience towards any kind of shock and stress. This is due to the fact that higher the literacy rate, higher the adaptive capacity, higher the appropriation of opportunities and higher the awareness to face any pressure. The literacy rate in Karnataka state has considerably increased in recent years. The coastal district of Dakshin Kannada has the highest literacy of $88.57 \%$ in the state. The other coastal districts such as Udupi and Uttara Kannada have recorded 86.24 and $84.06 \%$, respectively. The southern district of Bangalore Urban marks second with $87.67 \%$. Bidar district has $70.51 \%$ and Yadgiri has $51.83 \%$ literacy rate in the Hyderabad-Karnataka region. Yadgiri, Raichur and Bellary districts have lower literacy rates as compared to the rest of Karnataka. Poverty and lack of socio-economic development are the main reasons for poor literacy rate. Figure 9 shows the literacy rates across the districts of Karnataka. 


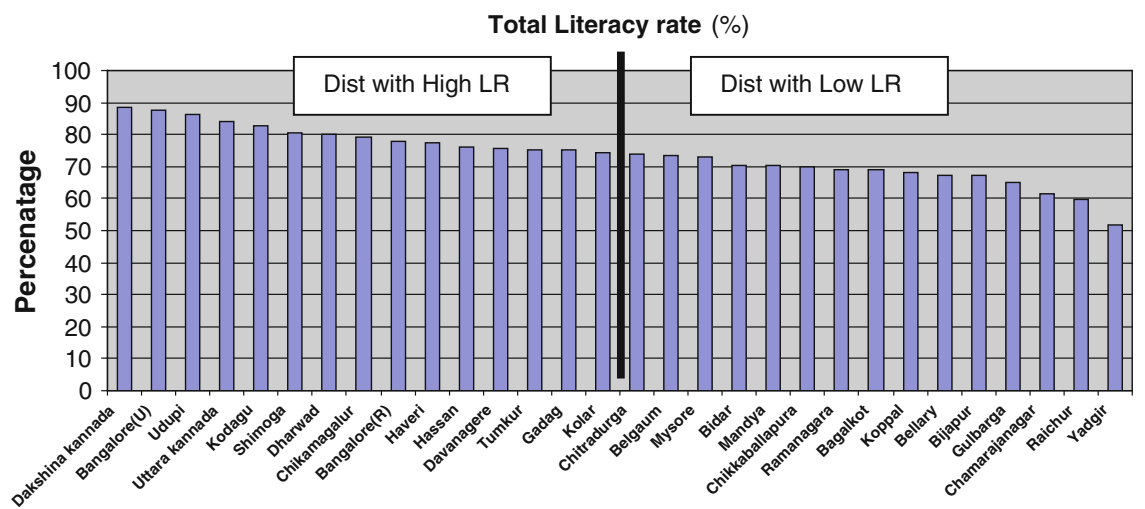

Fig. 9 Literacy rate $(L R)$ across the districts of Karnataka (based on Census of India, 2011)

\subsection{Marginal Landholders}

The size of landholdings is an important indicator for overall agricultural and socio-economic development. In Karnataka, majority of the farmers belong to the marginal landholdings category; Udupi district has the highest percentage $(79.8 \%)$ of marginal landholders (Fig. 10). Mandya, Ramanagara, Dakshin Kannada and Bangalore Urban districts also have significant percentage of marginal landholders. The size of landholding is greater in the northern districts as compared to the southern districts of Karnataka.

\section{$5.5 \quad$ Non-workers}

Higher the percentage of non-workers, higher will be the dependency rate. Higher dependency rate suggests the district is more vulnerable. This is due to the fact that

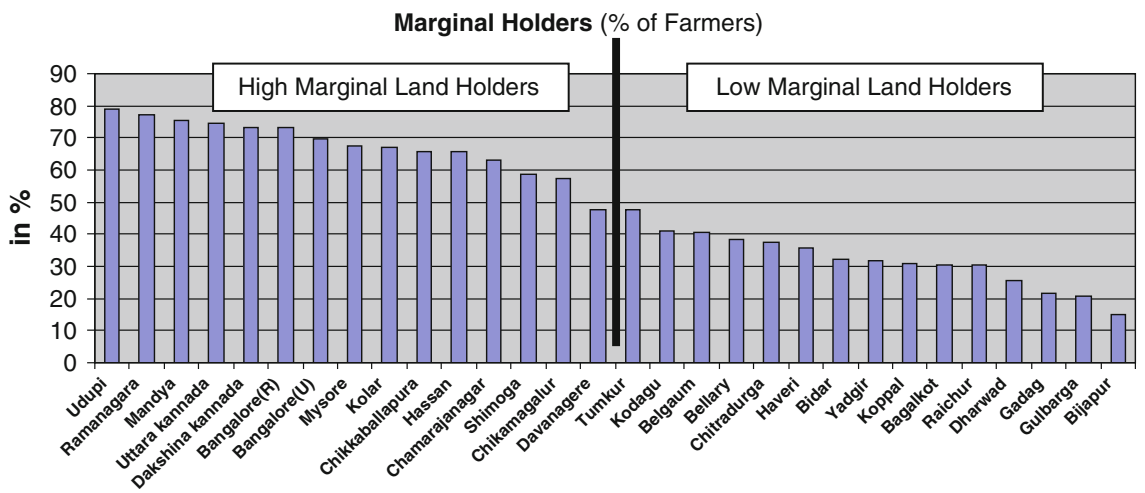

Fig. 10 Percentage of marginal landholders in different districts of Karnataka (based on the Directorate of Economics and Statistics, Agriculture census 2010-11) 
the number of persons having income source is less. The district of Bidar has $58.75 \%$ of non-workers, and is the highest in the state (Fig. 11). Other districts like Gulbarga, Uttara Kannada, Bijapur, Bagalkot, Mysore, Shimoga and Udupi also have a high percentage of non-workers. Figure 11 shows the percentage of non-workers across the districts of Karnataka.

\subsection{Livestock Units}

Livestock practices are considered as an important source of livelihood for rural communities. Agriculture and livestock are an integral part of the farmers' community. Livestock provides enormous opportunities to farmers to support their sustainable livelihood. The livestock units per lakh population is highest 58,431 in Yadgiri district and the lowest in Bangalore Urban district (1693) (Fig. 12). Districts like Belgaum, Tumkur and Chitradurg have higher numbers of livestock in absolute terms, however, the livestock units per lakh population is considered, Yadgiri ranks first. The southern districts of Karnataka are dominated by cross-breed cattle, since dairy development has taken place as a major source of economic activity in these districts. The central and northern Karnataka districts are dominated by sheep and goat. The districts of Dharwad, Bijapur, Bagalkot and Belgaum have more number of buffaloes.

\subsection{Per Capita Income}

One of the factors affecting the standard of living of people is per capita income. Higher the average per capita income, lesser is the levels of economic vulnerability.

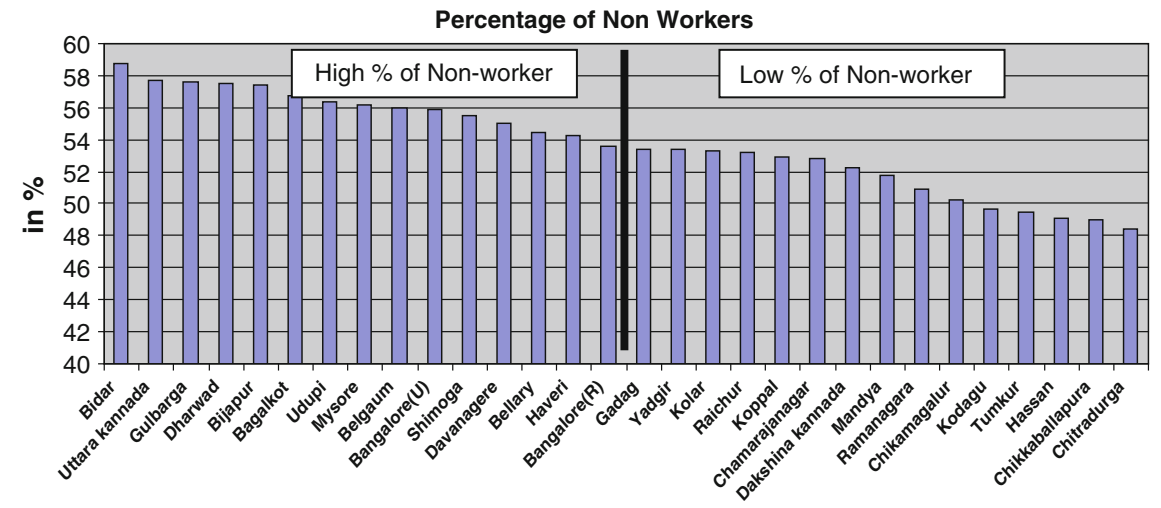

Fig. 11 Percentage of non-workers across the districts of Karnataka (based on the Census of India, 2011) 


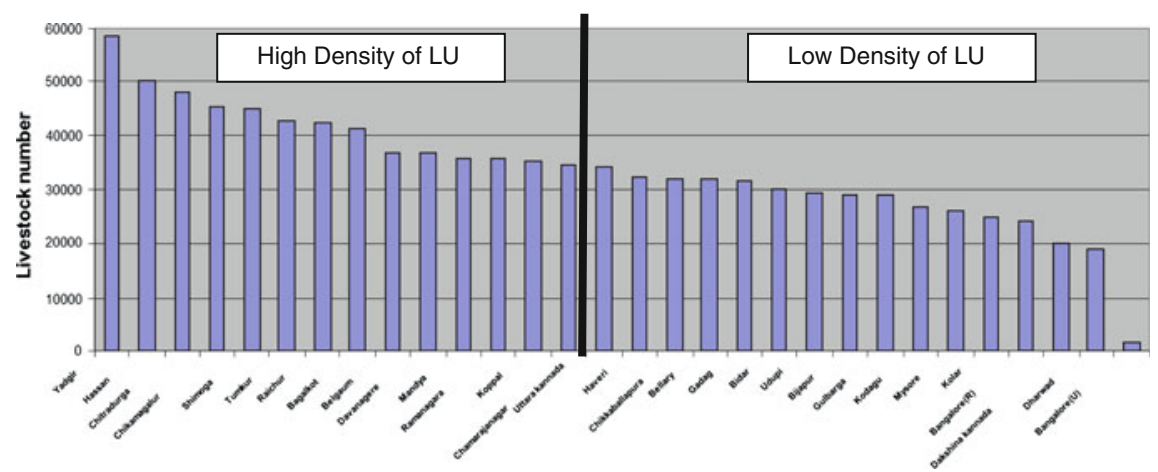

Fig. 12 Livestock units $(L U)$ per lakh population in the districts of Karnataka (based on Department of Animal Husbandry and Veterinary Services, Livestock Census 2007) (Note 1 livestock unit $(L U)=1 \mathrm{cow}=1$ buffalo $=5$ sheep $=5$ goats $)$

Bangalore Urban district has the highest per capita income of Rs. 139,033. Bangalore Rural and Kodagu have an average per capita income of Rs. 78,587 and Rs. 75,767, respectively. The Hyderabad-Karnataka region districts like Bidar, Gulbarga, Raichur, Yadgiri and Koppal have low per capita income in the state. Bidar district has the least (Rs. 26,905) per capita income in the state. In south Karnataka, the districts of Chamrajnagar and Mandya also have low per capita income. Figure 13 gives the details of per capita income (average of 3 years: 200809, 2009-10 and 2010-11) across the districts of Karnataka.

Table 2 presents all the districts of Karnataka, grouped into high and low incidence, indicating higher than the median value and lower than the median value, respectively, for all the indicators considered for assessment of livelihood and agricultural vulnerability.

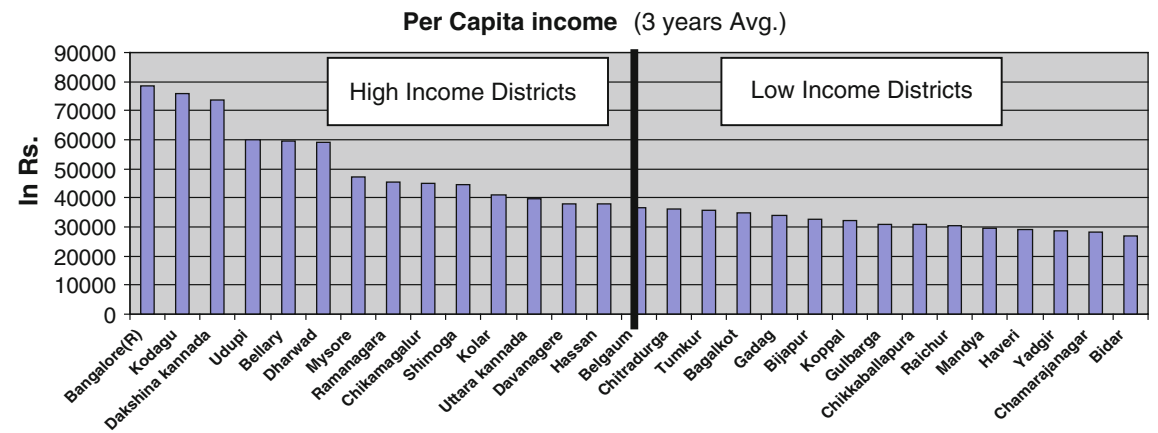

Fig. 13 Average per capita income across the districts of Karnataka (based on Directorate of Economics and Statistics published in Economy survey reports of Karnataka, 2010-11, 2011-12 and 2012-13) (Note Bangalore Urban is not included here as it is an outlier) 
Table 2 Districts with indicators grouped into high and low incidence

\begin{tabular}{|c|c|c|c|}
\hline No. & Indicators & $\begin{array}{l}\text { High incidence (from } \\
\text { median value) }\end{array}$ & $\begin{array}{l}\text { Low incidence (from } \\
\text { median value) }\end{array}$ \\
\hline \multicolumn{4}{|c|}{ Socio-economic and livelihood } \\
\hline 1 & Population density & $\begin{array}{l}\text { Mysore, Dharwad, } \\
\text { Bengaluru-R, Dakshin } \\
\text { Kannada, Kolar, Mandya, } \\
\text { Belgaum, Haveri, Udupi, } \\
\text { Davengere, Bidar, } \\
\text { Ramanagara, } \\
\text { Chikkaballapura, Bellery, } \\
\text { Bagalkot }\end{array}$ & $\begin{array}{l}\text { Hassan, Tumkur, Koppal, } \\
\text { Gulbarga, Gadag, Raichur, } \\
\text { Yadgiri, Shimoga, Bijapur, } \\
\text { Chitradurg, Chamrajnagar, } \\
\text { Chikmagalur, Uttara } \\
\text { Kannada, Kodagu }\end{array}$ \\
\hline 2 & $\%$ SC and ST population & $\begin{array}{l}\text { Chitradurg, Raichur, } \\
\text { Bellary, Chikkaballapura, } \\
\text { Bidar, Chamrajnagar, } \\
\text { Yadgiri, Kolar, Davengere, } \\
\text { Koppal, Mysore, Gulbarga, } \\
\text { Bengaluru-R, Tumkur, } \\
\text { Chikmagalur }\end{array}$ & $\begin{array}{l}\text { Kodagu, Haveri, Gadag, } \\
\text { Bijapur, Bagalkot, } \\
\text { Shimoga, Hassan, } \\
\text { Ramanagara, Belgaum, } \\
\text { Mandya, Bengaluru-U, } \\
\text { Dharwad, DK, Udupi and } \\
\text { Uttara Kannada }\end{array}$ \\
\hline 3 & $\%$ literacy rate & $\begin{array}{l}\text { Dakshin Kannada, } \\
\text { Bengaluru-U, Udupi. Uttara } \\
\text { Kannada, Kodagu, } \\
\text { Shimoga, Dharwad, } \\
\text { Chikmagalur, Bengaluru-R. } \\
\text { Haveri, Hassan, Davengere, } \\
\text { Tumkur, Gadag, Kolar }\end{array}$ & $\begin{array}{l}\text { Chitradurg, Belgaum, } \\
\text { Mysore, Bidar, Mandya, } \\
\text { Chikkaballapura, } \\
\text { Ramanagara, Bagalkot, } \\
\text { Koppal, Bellary, Bijapur, } \\
\text { Gulbarga, Chamrajnagar, } \\
\text { Raichur, Yadgiri }\end{array}$ \\
\hline 4 & $\begin{array}{l}\text { \% of marginal land holder } \\
(<1 \mathrm{ha})\end{array}$ & $\begin{array}{l}\text { Udupi Ramanagara, } \\
\text { Mandya. Uttara Kannada, } \\
\text { Dakshin Kannada, } \\
\text { Bengaluru-R, Bengaluru-U, } \\
\text { Mysore, Kolar, } \\
\text { Chikkaballapura, Hassan, } \\
\text { Chamrajnagar, Shimoga } \\
\text { Chikmagalur, Davengere }\end{array}$ & $\begin{array}{l}\text { Tumkur, Kodagu, Belgaum, } \\
\text { Bellary, Chitradurg, Haveri, } \\
\text { Bidar, Yadgiri, Koppal, } \\
\text { Bagalkot, Raichur, } \\
\text { Dharwad, Gadag, Gulbarga, } \\
\text { Bijapur }\end{array}$ \\
\hline 5 & $\%$ of non-workers & $\begin{array}{l}\text { Bidar, Uttara Kannada, } \\
\text { Gulbarga, Dharwad, } \\
\text { Bijapur, Bagalkot, Udupi } \\
\text { Mysore, Belgaum. } \\
\text { Bengaluru-U, Shimoga, } \\
\text { Dhabngr, Bellery, Haveri } \\
\text { Bengaluru-R }\end{array}$ & $\begin{array}{l}\text { Gadag, Yadgiri, Kolar, } \\
\text { Raichur, Koppal, } \\
\text { Chamrajnagar, Dakshin } \\
\text { Kannada, Mandya, } \\
\text { Ramanagara, Chikmagalur, } \\
\text { Kodagu, Tumkur, Hassan, } \\
\text { Chikkaballapura, } \\
\text { Chitradurg }\end{array}$ \\
\hline 6 & $\begin{array}{l}\text { Livestock units per lakh } \\
\text { population (livestock } \\
\text { unit }=1 \text { cattle }=1 \\
\text { buffalo }=5 \text { sheep }=5 \\
\text { goats) }\end{array}$ & $\begin{array}{l}\text { Yadgiri, Hassan, } \\
\text { Chitradurg, Chikmagalur, } \\
\text { Shimoga, Tumkur, Raichur, } \\
\text { Bagalkot, Belgaum, } \\
\text { Dhbngr, Mandya, } \\
\text { Ramanagara, Koppal, } \\
\text { Chamrajnagar and Uttara } \\
\text { Kannada }\end{array}$ & $\begin{array}{l}\text { Haveri, Chikkaballapura, } \\
\text { Bellary, Gadag, Bidar, } \\
\text { Udupi, Bijapur, Gulbarga, } \\
\text { Kodagu, Mysore, Kolar, } \\
\text { Bengaluru-R, Dakshin } \\
\text { Kannada, Dharwad, } \\
\text { Bengaluru-U }\end{array}$ \\
\hline
\end{tabular}


Table 2 (continued)

\begin{tabular}{|c|c|c|c|}
\hline No. & Indicators & $\begin{array}{l}\text { High incidence (from } \\
\text { median value) }\end{array}$ & $\begin{array}{l}\text { Low incidence (from } \\
\text { median value) }\end{array}$ \\
\hline 7 & $\begin{array}{l}\text { Per capita income ( } 3 \text { years } \\
\text { average) }\end{array}$ & $\begin{array}{l}\text { Bengaluru-R, Kodagui, } \\
\text { Dakshin Kannada, Udupi, } \\
\text { Bellary, Dharwad, Mysore, } \\
\text { Ramanagara, Chikmagalur, } \\
\text { Shimoga, Kolar, Uttara } \\
\text { Kannada, Davengere, } \\
\text { Hassan, }\end{array}$ & $\begin{array}{l}\text { Belgaum, Chitradurg, } \\
\text { Tumkur, Bagalkot, Gadag, } \\
\text { Bijapur, Koppal, Gulbarga, } \\
\text { Chikkaballapura, Raichur, } \\
\text { Mandya, Haveri, Yadgiri, } \\
\text { Chamrajnagar, Bidar }\end{array}$ \\
\hline 8 & Cropping intensity $(\mathrm{CI})$ & $\begin{array}{l}\text { Dharwad, Mysore, Gadag, } \\
\text { Koppal, Bellary, Belgaum, } \\
\text { Raichur, Bagalkot, Yadgiri, } \\
\text { Hassan, Davengere, } \\
\text { Chitradurg, DK, } \\
\text { Chamrajnagar }\end{array}$ & $\begin{array}{l}\text { Mandya, Udupi, Bijapur, } \\
\text { Shimoga, Bidar, Haveri, } \\
\text { Gulbarga, Tumkur, } \\
\text { Chikkaballapura, Uttara } \\
\text { Kannada, Chikmagalur, } \\
\text { Kolar, Kodagu, } \\
\text { Bengaluru-R, Ramanagara }\end{array}$ \\
\hline 9 & $\begin{array}{l}\% \text { of irrigated area to total } \\
\text { cropped area ( } 3 \text { years } \\
\text { average) }\end{array}$ & $\begin{array}{l}\text { Shimoga, Mandya, } \\
\text { Belgaum, Bagalkot, } \\
\text { Davengere, Bellary, } \\
\text { Dakshin Kannada, Yadgiri, } \\
\text { Raichur, Mysore, Koppal, } \\
\text { Bijapur, Chamrajnagar and } \\
\text { Tumkur }\end{array}$ & $\begin{array}{l}\text { Udupi, Hassan, } \\
\text { Ramanagara, } \\
\text { Chikkaballapura, Uttara } \\
\text { Kannada, Bengaluru-R, } \\
\text { Haveri, Kolar, Chitradurg, } \\
\text { Gulbarga, Gadag, Dharwad, } \\
\text { Bidar, Chikmagalur, } \\
\text { Kodagu }\end{array}$ \\
\hline 10 & $\begin{array}{l}\text { Total area under crops such } \\
\text { as mango, grapes, } \\
\text { pomegranate, citrus, } \\
\text { papaya, cashew nut and } \\
\text { others }\end{array}$ & $\begin{array}{l}\text { Kolar, Dakshin Kannada, } \\
\text { Udupi, Tumkur, } \\
\text { Ramanagara, } \\
\text { Chikkaballapura, Bijapur, } \\
\text { Shimoga, Mysore, } \\
\text { Bengaluru-R, Dharwad, } \\
\text { Chamrajnagar, Belgaum, } \\
\text { Koppal, Hassan } \\
\end{array}$ & $\begin{array}{l}\text { UK, Chitradurg, Bellary, } \\
\text { Bagalkot, Kodagu, Dhvngr, } \\
\text { Chikmagalur, Haveri, } \\
\text { Mandya, Gul, Bengaluru-U, } \\
\text { Bidar, Yadgiri, Gadag, } \\
\text { Raichur }\end{array}$ \\
\hline \multicolumn{4}{|c|}{ Agriculture } \\
\hline 1 & $\begin{array}{l}\text { Net sown area ( } 3 \text { years } \\
\text { average) }\end{array}$ & $\begin{array}{l}\text { Gulbarga, Gadag, Bijapur, } \\
\text { Haveri, Dharwad, Gglkt, } \\
\text { Koppal, Davengere, Bidar, } \\
\text { Yadgiri, Belgaum, Raichur, } \\
\text { Hassan Chitradurg, Tumkur }\end{array}$ & $\begin{array}{l}\text { Bengaluru-R, Bellary, } \\
\text { Mysore, Mandya, } \\
\text { Ramanagara, Kolar, } \\
\text { Chikkaballapura, } \\
\text { Chikmagalur, Kodagu, } \\
\text { Chamrajnagar, Udupi, } \\
\text { Dakshin Kannada, } \\
\text { Shimoga, Uttara Kannada }\end{array}$ \\
\hline 2 & Cropping intensity & $\begin{array}{l}\text { Dharwad, Mysore, Gadag, } \\
\text { Koppal, Bellary, Belgaum, } \\
\text { Raichur, Bagalkot, Yadgiri, } \\
\text { Hassan, Dhvngr, } \\
\text { Chitradurg, DK, } \\
\text { Chamrajnagar }\end{array}$ & $\begin{array}{l}\text { Mandya, Udupi, Bijapur, } \\
\text { Shimoga. Bidar, Haveri, } \\
\text { Gulbarga, Tumkur, } \\
\text { Chikkaballapura, Uttara } \\
\text { Kannada, Chikmagalur, } \\
\text { Kolar, Kodagu, } \\
\text { Bengaluru-R, Ramanagara }\end{array}$ \\
\hline
\end{tabular}


Table 2 (continued)

\begin{tabular}{|c|c|c|c|}
\hline No. & Indicators & $\begin{array}{l}\text { High incidence (from } \\
\text { median value) }\end{array}$ & $\begin{array}{l}\text { Low incidence (from } \\
\text { median value) }\end{array}$ \\
\hline 3 & $\begin{array}{l}\% \text { area under commercial } \\
\text { crops to TCA }\end{array}$ & $\begin{array}{l}\text { Belgaum, Haveri, Mysore, } \\
\text { Dharwad, Bagalkot, } \\
\text { Mandya, Gadag, Yadgiri, } \\
\text { Bidar, Bellary, } \\
\text { Chamrajnagar, Bijapur, } \\
\text { Dhngr, Gulbarga }\end{array}$ & $\begin{array}{l}\text { Hassan, Raichur, Koppal, } \\
\text { Shimoga, Uttara Kannada, } \\
\text { Chitradurg, Chikmagalur, } \\
\text { Ramanagara, Tumkur, } \\
\text { Kodagu, Kolar, } \\
\text { Chikkaballapura, Udupi, } \\
\text { Bengaluru-R, Dakshin } \\
\text { Kannada }\end{array}$ \\
\hline 4 & $\begin{array}{l}\% \text { irrigated area to TCA } \\
(3 \text { years average) }\end{array}$ & $\begin{array}{l}\text { Shimoga, Mandya, } \\
\text { Belgaum, Bagalkot, } \\
\text { Dhvngr, Bellary, Dakshin } \\
\text { Kannada, Yadgiri, Raichur, } \\
\text { Mysore, Koppal, Bijapur, } \\
\text { Chamrajnagar, and Tumkur }\end{array}$ & $\begin{array}{l}\text { Udupi, Hassan, } \\
\text { Ramanagara, } \\
\text { Chikkaballapura, UK, } \\
\text { Bengaluru-R, Haveri, } \\
\text { Kolar, Chitradurg, } \\
\text { Gulbarga, Gadag, Dharwad, } \\
\text { Bidar, Chikmagalur, } \\
\text { Kodagu }\end{array}$ \\
\hline 5 & $\begin{array}{l}\text { No. of tractors } / 1000 \text { ha area } \\
\text { sown }\end{array}$ & $\begin{array}{l}\text { Kolar, Ramanagara, } \\
\text { Dharwad, Dakshin } \\
\text { Kannada, Shimoga, } \\
\text { Chikkaballapura, Dhvngr, } \\
\text { Udupi, Kodagu, } \\
\text { Chikmagalur, Hassan, } \\
\text { Belgaum, Uttara Kannada, } \\
\text { Bengaluru-R, Tumkur }\end{array}$ & $\begin{array}{l}\text { Bellary, Bagalkot, Mysore, } \\
\text { Mandya, Haveri, Raichur, } \\
\text { Chitradurg, Koppal, Gadag, } \\
\text { Yadgiri, Bijapur, Gul, } \\
\text { Chamrajnagar, Bidar }\end{array}$ \\
\hline 6 & $\begin{array}{l}\% \text { of total fallow land to } \\
\text { total geographical area } \\
\text { (3 years average) }\end{array}$ & $\begin{array}{l}\text { Raichur, Yadgiri, Bidar, } \\
\text { Koppal, Kolar, Bellary, } \\
\text { Bijapur, Belgaum, Mandya, } \\
\text { Tumkur, Mysore, Dharwad, } \\
\text { Hassan, Ramanagara }\end{array}$ & $\begin{array}{l}\text { Bengaluru-R, Chitradurg, } \\
\text { Gulbarga, Chikkaballapura, } \\
\text { Bagalkot, Shimoga, } \\
\text { Chamrajnagar, Gadag, } \\
\text { Haveri, Dhvngr, } \\
\text { Chikmagalur, Udupi, } \\
\text { Dakshin Kannada, Kodagu } \\
\text { and Uttara Kannada }\end{array}$ \\
\hline 7 & $\begin{array}{l}\text { No. of agricultural } \\
\text { cooperative credit } \\
\text { societies/lakh population }\end{array}$ & $\begin{array}{l}\text { Belgaum, Gadag, Haveri, } \\
\text { Mandya, Kodagu, Hassan, } \\
\text { Bijapur, UK, Bagalkot, } \\
\text { Bidar, Chikmagalur, } \\
\text { Dhvngr, Shimoga, Tumkur }\end{array}$ & $\begin{array}{l}\text { Chitradurg, Dharwad, } \\
\text { Chikkaballapura, } \\
\text { Ramanagara, } \\
\text { Chamrajnagar, } \\
\text { Bengaluru-R, Yadgiri, } \\
\text { Kolar, Koppal, Mysore, } \\
\text { Raichur, Gulbarga, Bellary, } \\
\text { Dakshin Kannada, Udupi }\end{array}$ \\
\hline
\end{tabular}




\section{Approach to Vulnerability Assessment}

Vulnerability is often reflected in the state of the economic system as well as the socio-economic features of the population living in that system. The current section of the report attempts to build a picture of the socio-economic context of vulnerability by focusing on indicators that measure both the state of development of the people as well as its capacity to progress further. In addition, attempt has been made to construct a vulnerability index for each district of Karnataka and rank them in terms of their performance on the index. The index attempts to capture the comprehensive scale of vulnerability by considering some of the key indicators (that serve as proxies) for the assessment (Table 3).

There is consensus among researchers to address vulnerability issues at the regional level (Hiremath and Shiyani 2013). Therefore districts have been taken as a unit for developing vulnerability indices. In the next step we have selected important indicators for the vulnerability assessment. After the selection of indicators, data pertinent to the selected indicators were compiled (Table 3). In the next step, a Principal component analysis (PCA) was conducted to identify variability among the selected variables and finally vulnerability indices were developed. Figure 14 presents the details of the method adopted for assessment of vulnerability across the districts of Karnataka.

\subsection{Principal Component Analysis (PCA)}

A PCA was conducted to identify the variability among selected variables (indicators) for this study. PCA is a data reduction methodology that identifies smaller number of components that explains most of the variance observed in the larger data set. The goal is to arrive at a minimum number of components that will adequately account for the covariation among the larger number of analysis variables. PCA is a tool that converts a number of potentially correlated variables into a set of uncorrelated variables that capture the variability in the underlying data. It is a statistical method that thus transforms a given data set to a smaller number of uncorrelated variables called principal components (PCs). The first PC accounts for a large share of variability in the data, and each succeeding component accounts for as much of the remaining variability as possible. PCA approach provides several potential advantages in the aggregation of spatially explicit, potentially incommensurable variables. When the original variables are correlated then the higher order PCs will capture more of the total variability in the data than any individual original variable. Excluding the lower order PCs reduces the dimensionality (number of variables) of the data while minimizing the loss of information (Smith 2002). PCA thus helps reduce from a large number of individual indicators to a small number of composite, unitless indices (PCs) while reducing the trade-off between richness of information and communicability. 
Table 3 Indicators used in this study and rationale

\begin{tabular}{|c|c|c|}
\hline No. & Indicators & Rationality \\
\hline \multicolumn{3}{|c|}{ Socio-economic and livelihoods } \\
\hline 1 & Population density & $\begin{array}{l}\text { Higher the density, more dependency on finite } \\
\text { resources and lower the availability of resources }\end{array}$ \\
\hline 2 & Percentage of SC and ST population & $\begin{array}{l}\text { They are among the poor and vulnerable (both } \\
\text { socially and economically) }\end{array}$ \\
\hline 3 & Literacy rate & $\begin{array}{l}\text { Higher the literacy rate, higher the adaptation } \\
\text { capacity, higher the appropriation of opportunities } \\
\text { and higher the awareness to face any shock and } \\
\text { stress }\end{array}$ \\
\hline 4 & $\begin{array}{l}\text { Percentage of marginal land holders } \\
(<1 \text { ha })\end{array}$ & $\begin{array}{l}\text { Higher the proportion of marginal farmers, lesser } \\
\text { the production and income and thus higher the } \\
\text { vulnerability }\end{array}$ \\
\hline 5 & Percentage of non-workers & $\begin{array}{l}\text { More unemployment, more dependency, lower } \\
\text { will be the earning capacity and income as } \\
\text { compared to expenditure and thus higher } \\
\text { vulnerability }\end{array}$ \\
\hline 6 & Livestock units per lakh population & $\begin{array}{l}\text { Animal husbandry is an important source of } \\
\text { livelihood for rural communities. Livestock } \\
\text { provides alternate sources of income to farmers, } \\
\text { thus supporting their sustainable livelihood }\end{array}$ \\
\hline 7 & Per capita income ( 3 years average) & Higher per capita, higher standard of living \\
\hline 8 & Cropping intensity & $\begin{array}{l}\text { Higher cropping intensity means that a higher } \\
\text { portion of the net area is being cropped more than } \\
\text { once during one agricultural year. Higher } \\
\text { cropping intensity, greater is the efficiency of land } \\
\text { use }\end{array}$ \\
\hline 9 & $\begin{array}{l}\text { Percentage irrigated area to total } \\
\text { cropped area ( } 3 \text { years average })\end{array}$ & $\begin{array}{l}\text { Irrigation protects crop production in the light of } \\
\text { climate variations and extremes like drought }\end{array}$ \\
\hline 10 & Total area under fruit crops & Alternative source of farm based income \\
\hline \multicolumn{3}{|c|}{ Agriculture } \\
\hline 1 & Net sown area (3 years average) & Represents the total area sown with crops \\
\hline 2 & Cropping intensity & $\begin{array}{l}\text { Higher cropping intensity means that a higher } \\
\text { portion of the net area is being cropped more than } \\
\text { once during one agricultural year. Higher } \\
\text { cropping intensity, greater is the efficiency of land } \\
\text { use }\end{array}$ \\
\hline 3 & $\begin{array}{l}\text { Percentage of area under } \\
\text { commercial crops to TCA }\end{array}$ & $\begin{array}{l}\text { Higher the area under commercial crops, lesser } \\
\text { vulnerability (market linkage) } \\
\text { High value cash crops represent one potential } \\
\text { avenue of crop intensification }\end{array}$ \\
\hline 4 & $\begin{array}{l}\text { Percentage of irrigated area to TCA } \\
\text { (3 years average) }\end{array}$ & $\begin{array}{l}\text { Irrigation has the potential to provide higher yields } \\
\text { than rainfed agriculture and reduce the insecurity } \\
\text { of crop production }\end{array}$ \\
\hline
\end{tabular}


Table 3 (continued)

\begin{tabular}{l|l|l}
\hline No. & Indicators & Rationality \\
\hline 5 & No. of tractors/1000 ha area sown & $\begin{array}{l}\text { More tractors for agricultural activities } \\
\text { (mechanization), increase the efficiency in } \\
\text { production }\end{array}$ \\
\hline 6 & $\begin{array}{l}\text { \% fallow land as proportion of total } \\
\text { graphical area (3 years average) }\end{array}$ & $\begin{array}{l}\text { Higher fallow land means more non utilization of } \\
\text { resources }\end{array}$ \\
\hline 7 & $\begin{array}{l}\text { No. of agricultural cooperative } \\
\text { credit societies/lakh population }\end{array}$ & $\begin{array}{l}\text { It is a grass roots financial institution and provides } \\
\text { credit to farmers in times of need, securing crop } \\
\text { production }\end{array}$ \\
\hline
\end{tabular}

Above indicators have been selected based on consultation with experts, and studies reported (Hiremath and Shiyani 2013; Khan and Salman 2012; Swain and Swain 2011; ICRISAT 2009)

Vulnerability is the degree to which a system is susceptible to, or unable to cope with adverse effects of climate change, including climate variability and extremes. Vulnerability is a function of the character, magnitude and rate of climate change to which a system is exposed, along with its sensitivity and adaptive capacity.

Exposure is the nature and degree to which a system is exposed to significant climatic variations

Sensitivity is the degree to which a system can be affected, negatively or positively, by changes in climate. This includes change in mean climate and the frequency and magnitude of extremes. The effect may be direct (for example, a change in crop yield due to a change in temperature) or indirect (such as damage caused by increased frequency of coastal flooding due to sea-level rise).

Adaptive Capacity is a system's ability to adjust to climate change (including climate variability and extremes), to moderate potential damage, and to take advantage of opportunities or to cope with consequences.

Source: IPCC, Fourth Assessment Report, 2007

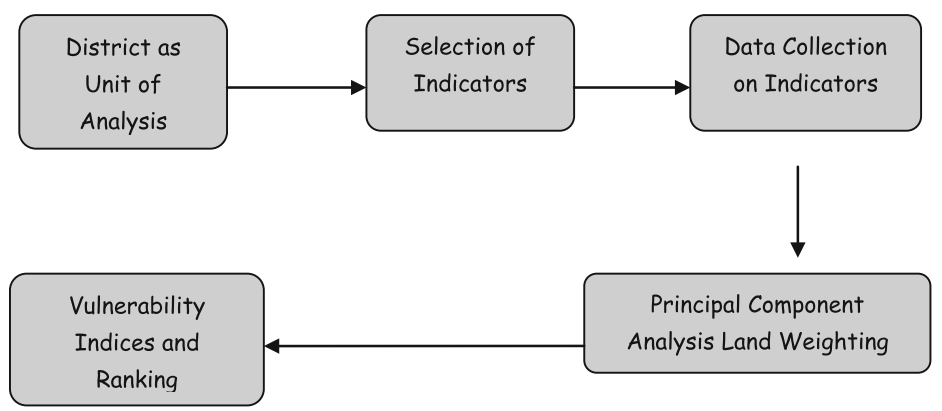

Fig. 14 Framework of assessment of vulnerability

PCA helped with generation of the weights, based on the assumption that there are common factors that explain the variance in the vulnerability. Varimax rotation was performed on the results of the PCA to maximize the variance accounted by the first component. Only components with Eigen values $>1$ were included in the analysis. 
Table 4 Total variance explained by principal components for agricultural vulnerability

\begin{tabular}{l|l|l|l|l|l|l}
\hline Component & \multicolumn{3}{|l|}{ Initial Eigen values } & \multicolumn{3}{|c}{ Rotation sums of squared loadings } \\
\hline & Total & \% variance & Cumulative \% & Total & $\%$ variance & Cumulative \% \\
\hline 1 & 2.192 & 31.309 & 31.309 & 1.815 & 25.924 & 25.924 \\
\hline 2 & 1.566 & 22.369 & 53.678 & 1.659 & 23.699 & 49.623 \\
\hline 3 & 1.292 & 18.454 & 72.133 & 1.576 & 22.510 & 72.133 \\
\hline 5 & 0.836 & 11.946 & 84.079 & & & \\
\hline 6 & 0.543 & 7.754 & 91.832 & & & \\
\hline 7 & 0.385 & 5.504 & 97.337 & & & \\
\hline
\end{tabular}

Table 5 Total variance explained by principal components for socio-economic and livelihood vulnerability

\begin{tabular}{l|l|l|l|l|l|l}
\hline \multirow{2}{*}{ Component } & \multicolumn{3}{|l|}{ Initial Eigen values } & \multicolumn{3}{l}{ Rotation sums of squared loadings } \\
\cline { 2 - 7 } & Total & $\%$ variance & Cumulative \% & Total & $\%$ variance & Cumulative \% \\
\hline 1 & 3.531 & 35.307 & 35.307 & 3.086 & 30.856 & 30.856 \\
\hline 2 & 1.825 & 18.247 & 53.553 & 2.032 & 20.315 & 51.171 \\
\hline 3 & 1.328 & 13.284 & 66.837 & 1.567 & 15.666 & 66.837 \\
\hline 4 & 0.995 & 9.953 & 76.790 & & & \\
\hline 5 & 0.795 & 7.949 & 84.739 & & & \\
\hline 6 & 0.651 & 6.507 & 91.246 & & & \\
\hline 7 & 0.355 & 3.545 & 94.792 & & & \\
\hline 8 & 0.234 & 2.341 & 97.132 & & & \\
\hline 9 & 0.163 & 1.629 & 98.762 & & & \\
\hline 10 & 0.124 & 1.238 & 100.000 & & & \\
\hline
\end{tabular}

Based on Statistical Packages for Social Sciences output, the findings of the study for the agriculture and socio-economic based classification on vulnerability indicators revealed three components, each with Eigen values greater than 1 (Tables 4 and 5). These two PCA results explain 72 and $67 \%$ of the total variation in the two data sets.

There is subjectivity in assigning weights to indicators in vulnerability assessments. In order to overcome this problem, we employed the PCA technique through which we reduced the number of variables and also obtained weights (Eigen values) for the PCs. In the present study, weights are not therefore arbitrarily assigned but determined endogenously from the data matrix. The weights of the PCs are the corresponding Eigen values (Tables 6 and 7; Figs. 15 and 16). 
Table 6 Agricultural vulnerability index (Principal component analysis) for Eigen value $(E)$

\begin{tabular}{|c|c|c|c|c|c|c|}
\hline No. & District & $\begin{array}{l}\text { Component } 1 \\
\text { (E1) } 2.192\end{array}$ & $\begin{array}{l}\text { Component } 2 \\
\text { (E2) } 1.566\end{array}$ & \begin{tabular}{|l|} 
Component 3 \\
(E3) 1.292
\end{tabular} & $\begin{array}{l}\text { Composite } \\
\text { index }\end{array}$ & Rank \\
\hline 1 & Kolar & -0.85511 & -1.11939 & -0.73926 & -0.90742 & 1 \\
\hline 2 & Ramanagara & -0.87804 & -1.27245 & -0.15289 & -0.81482 & 2 \\
\hline 3 & Chikkaballapura & -0.82441 & -1.07869 & -0.05907 & -0.70746 & 3 \\
\hline 4 & Bangalore(R) & -1.16193 & -0.16957 & -0.49661 & -0.68398 & 4 \\
\hline 5 & Chikmagalur & -1.3684 & -0.58613 & 0.77913 & -0.57639 & 5 \\
\hline 6 & Kodagu & -1.71026 & -0.42877 & 1.3934 & -0.51883 & 6 \\
\hline 7 & Shimoga & 0.62477 & -2.61467 & 0.15007 & -0.50123 & 7 \\
\hline 8 & Tumkur & -0.62399 & -0.1713 & -0.47779 & -0.44621 & 8 \\
\hline 9 & Chitradurg & -0.80222 & 0.36051 & -0.21221 & -0.29071 & 9 \\
\hline 10 & Chamrajnagar & -0.4255 & -0.39351 & 0.06777 & -0.28938 & 10 \\
\hline 11 & Raichur & 0.60885 & 0.43638 & -2.4042 & -0.2155 & 11 \\
\hline 12 & Bellary & 0.65088 & -0.41453 & -1.20227 & -0.15362 & 12 \\
\hline 13 & Koppal & 0.16297 & 0.71543 & -1.23653 & -0.02376 & 13 \\
\hline 14 & Gulbarga & -1.05421 & 1.79857 & -0.46937 & -0.01994 & 14 \\
\hline 15 & Hassan & -0.14221 & -0.02496 & 0.29463 & 0.005911 & 15 \\
\hline 16 & Davengere & 0.39099 & -0.87883 & 0.54725 & 0.037198 & 16 \\
\hline 17 & Bidar & -0.73042 & 1.47056 & -0.29887 & 0.06251 & 17 \\
\hline 18 & Yadgiri & 0.5131 & 0.66057 & -1.3445 & 0.083579 & 18 \\
\hline 19 & Bijapur & -0.17298 & 1.34544 & -0.04336 & 0.331043 & 19 \\
\hline 20 & Mandya & 1.18009 & -0.61425 & 0.38476 & 0.420188 & 20 \\
\hline 21 & Bagalkot & 1.08404 & 0.13255 & 0.59092 & 0.662823 & 21 \\
\hline 22 & Dharwad & 1.29482 & 0.3963 & 0.11332 & 0.713913 & 22 \\
\hline 23 & Mysore & 2.00556 & -0.00639 & -0.39 & 0.768772 & 23 \\
\hline 24 & Gadag & -0.03265 & 1.6015 & 1.63404 & 0.900507 & 24 \\
\hline 25 & Haveri & 0.32733 & 0.91954 & 2.21027 & 0.992708 & 25 \\
\hline 26 & Belgaum & 1.93892 & -0.06391 & 1.36136 & 1.170081 & 26 \\
\hline
\end{tabular}

Source Based on Directorate of Economics and Statistics, Ministry of Agriculture, 2008-09, 2009-10 and 2010-11

Note Bangalore (U) is not included in the construction of vulnerability index. This is due to the fact that Bangalore (U) is the capital city of Karnataka and since last one decade agricultural activities have been reduced rapidly. It was observed that in some districts of Western Ghats region, agricultural indicators are performing very poor and also affecting index values of other districts while constructing vulnerability index. Therefore, we consider Bangalore (U), Uttara Kannada, Dakshin Kannada and Udupi as outlier districts and excluded from agricultural vulnerability index analysis

Composite Index $=E 1 *$ fact $1+E 2 *$ fact $2+E 3 *$ fact $3 / E 1+E 2+E 3$

Weight $1=E 1 / E 1+E 2+E 3$, Weight $2=E 2 / E 1+E 2+E 3$, Weight $3=E 3 / E 1+E 2+E 3$

Weight for Factor $1=0.434059$, Weight for Factor $2=0.310099$ and Weight for Factor $3=0.255842$ 
Table 7 Socio-economic and livelihood vulnerability index (Principal component analysis for Eigen value $(E)$

\begin{tabular}{l|l|l|l|l|l|l}
\hline No. & Districts & $\begin{array}{l}\text { Component } 1 \\
(E 1) 3.53\end{array}$ & $\begin{array}{l}\text { Component } 2 \\
(E 2) 1.82\end{array}$ & $\begin{array}{l}\text { Component } 3 \\
(E 3) 1.32\end{array}$ & $\begin{array}{l}\text { Composite } \\
\text { index }\end{array}$ & Rank \\
\hline 1 & Yadgiri & -1.4647 & -1.2176 & 0.0553 & -1.0952 & 1 \\
\hline 2 & Chitradurg & -0.7278 & -0.7424 & -1.6660 & -0.9182 & 2 \\
\hline 3 & Raichur & -0.8808 & -1.3046 & 0.0125 & -0.8190 & 3 \\
\hline 4 & Chamrajnagar & -0.7335 & -0.2774 & -0.5385 & -0.5702 & 4 \\
\hline 5 & Chikkaballapura & -0.5914 & 0.3343 & -1.5872 & -0.5364 & 5 \\
\hline 6 & Tumkur & -0.7033 & 0.6696 & -0.9432 & -0.3761 & 6 \\
\hline 7 & Chikkamagalur & -0.1782 & 0.0340 & -1.4241 & -0.3678 & 7 \\
\hline 8 & Koppal & -0.4457 & -0.6864 & 0.2939 & -0.3644 & 8 \\
\hline 9 & Hassan & -0.6769 & 0.5739 & -0.6387 & -0.3278 & 9 \\
\hline 10 & Bidar & 0.2911 & -1.5959 & -0.0977 & -0.3013 & 10 \\
\hline 11 & Gulbarga & 0.1991 & -1.4325 & 0.1460 & -0.2569 & 11 \\
\hline 12 & Bellary & -0.1886 & -0.7484 & 0.3989 & -0.2247 & 12 \\
\hline 13 & Gadag & 0.2242 & -1.1114 & 0.2768 & -0.1299 & 13 \\
\hline 14 & Ramanagara & -0.3164 & 1.0652 & -1.0845 & -0.0917 & 14 \\
\hline 15 & Davengere & -0.3537 & -0.0738 & 0.5905 & -0.0897 & 15 \\
\hline 16 & Bagalkot & -0.4631 & -0.3315 & 1.3301 & -0.0708 & 16 \\
\hline 17 & Haveri & 0.1526 & -0.4582 & -0.1074 & -0.0658 & 17 \\
\hline 18 & Bijapur & -0.0531 & -0.5579 & 0.8446 & -0.0125 & 18 \\
\hline 19 & Kolar & -0.2010 & 1.3257 & -1.0409 & 0.0489 & 19 \\
\hline 20 & Kodagu & 0.9383 & -0.4084 & -1.6853 & 0.0493 & 20 \\
\hline 21 & Mandya & -0.6866 & 1.0867 & 0.6148 & 0.0561 & 21 \\
\hline 22 & Belgaum & -0.2871 & 0.2015 & 1.4086 & 0.1831 & 22 \\
\hline 23 & Shimoga & -0.6208 & 1.1761 & 1.1372 & 0.2191 & 23 \\
\hline 24 & Mysore & 0.1396 & -0.0234 & 1.4892 & 0.3632 & 24 \\
\hline 25 & Bangalore (R) & 0.7940 & 0.4613 & -0.8811 & 0.3703 & 25 \\
\hline 27 & Uttara Kannada & 0.3738 & 0.9583 & 0.5949 & 0.5773 & 26 \\
\hline 28 & Dharwad & 1.1340 & -0.7334 & 1.8957 & 0.7754 & 27 \\
\hline 29 & Udupi & 0.5460 & 1.6941 & 0.6713 & 0.8843 & 28 \\
\hline & Kakshin & 0.5001 & 2.5343 & 0.5759 & 1.0705 & 29 \\
\hline 30 & Bangalore $(\mathrm{U})$ & 4.2800 & -0.4116 & -0.6419 & 2.0211 & 30 \\
\hline Bara & & & & & 1 \\
\hline
\end{tabular}

Source Based on Census of India 2011, Agricultural Census 2010-11, Directorate of Economics and Statistics, Ministry of Agriculture, 2008-09, 2009-10 and 2010-11 and Livestock Census 2007

Note Composite Index $=E 1 *$ fact $1+E 2 *$ fact $2+E 3 *$ fact $3 / E 1+E 2+E 3$

Weight $1=E 1 / E 1+E 2+E 3$, Weight $2=E 2 / E 1+E 2+E 3$, Weight $3=E 3 / E 1+E 2+E 3$

Weight for Factor $1=0.528276$, Weight for Factor $2=0.27304$ and Weight for Factor $3=0.198683$ 


\section{Weights for Components (Agriculture) Generated by PCA}

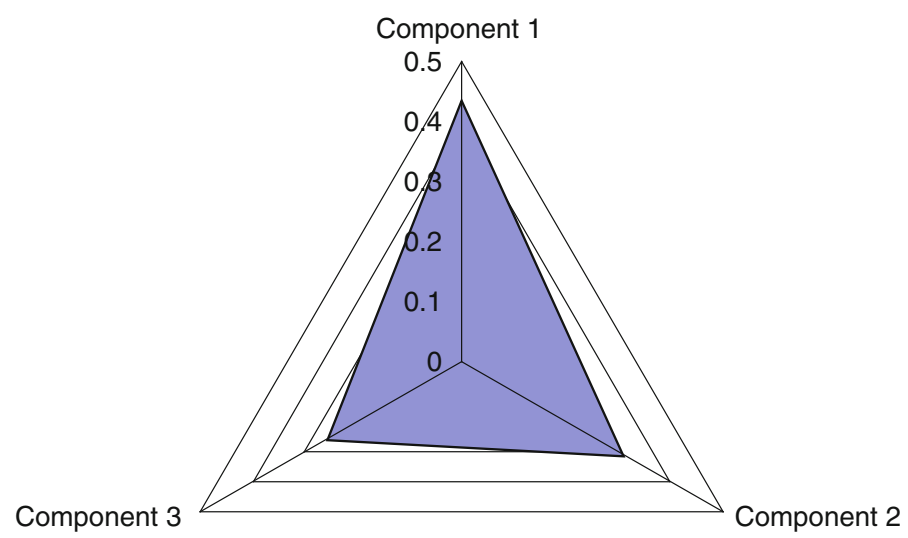

Fig. 15 Weights for agricultural component indicators generated by PCA

\section{Weights for Comonents (Livelihoods) Generated by PCA Component 1}

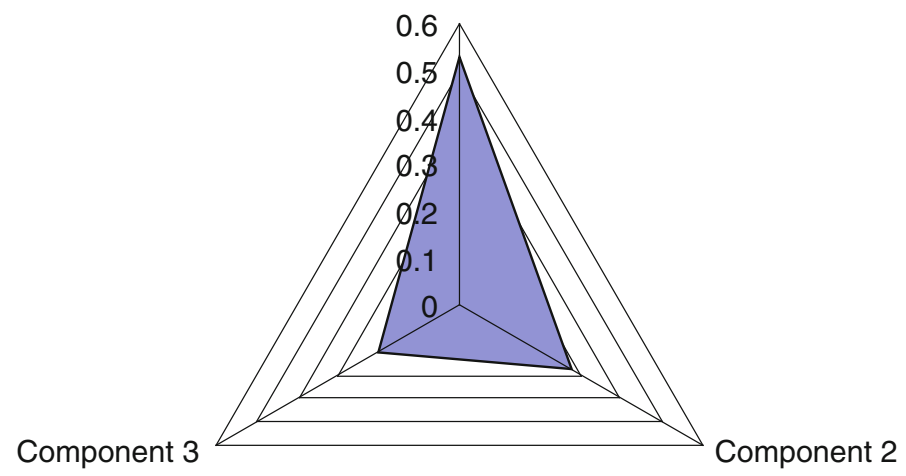

Fig. 16 Weights for socio-economic component Indicators generated by PCA

\section{Agricultural Vulnerability Index for the Districts of Karnataka}

In the present study, 7 indicators were considered for the development of agricultural vulnerability index (Table 3). Based on PCA, agricultural vulnerability index values for all the districts of Karnataka are given in Table 6. Rank 1 indicates maximum vulnerability and the vulnerability decreases with increasing rank. Figure 17 depicts the agricultural vulnerability of the districts of Karnataka. Areas in red are the most vulnerable districts and those in green are the least vulnerable 


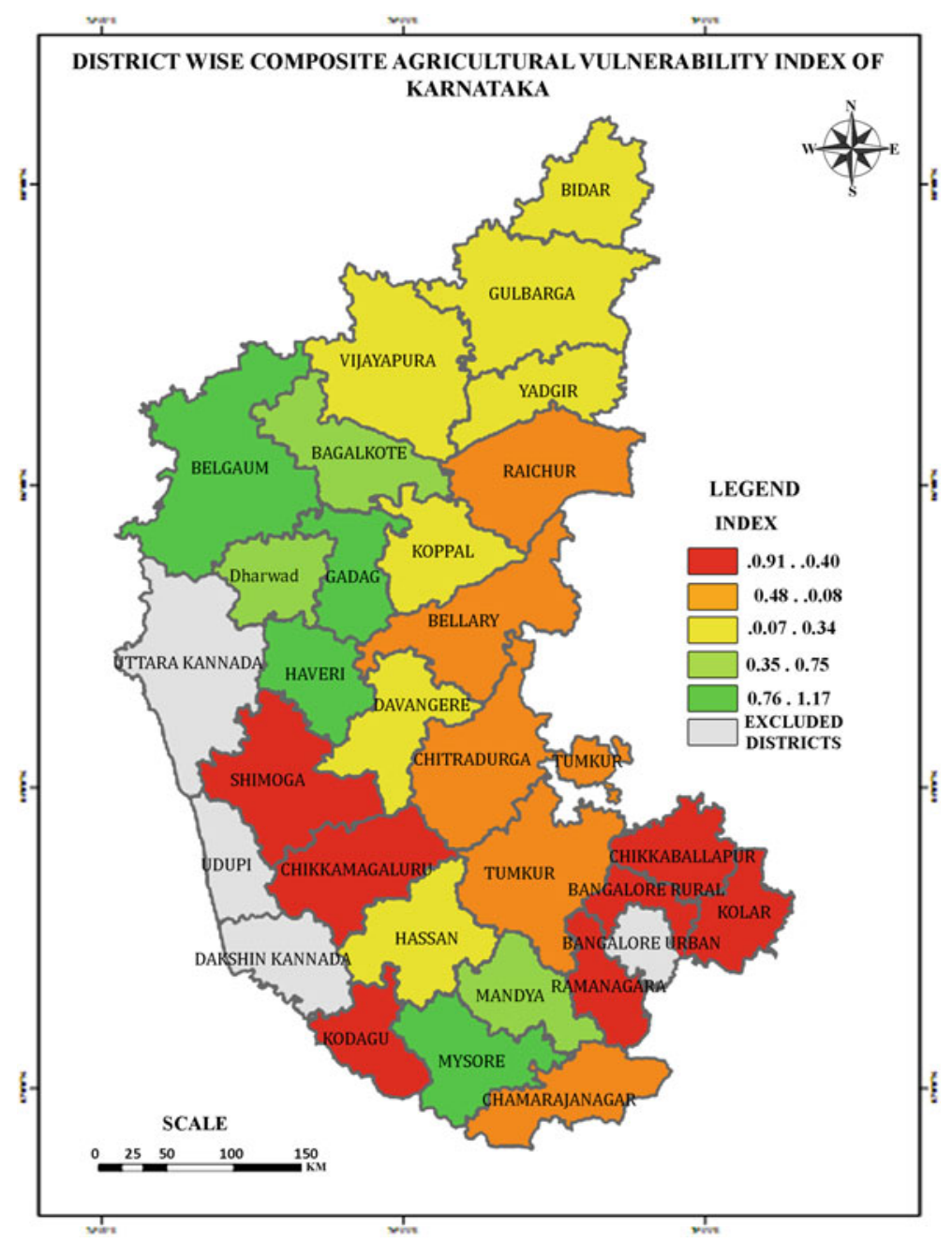

Fig. 17 Agricultural vulnerability index (Note Areas in red are the most agriculturally vulnerable districts and those in green are the least vulnerable districts of Karnataka. Bangalore (U) is not included)

districts of Karnataka. Table 8 gives the details of significance of variables that explain variation in each component.

- The rotated factor analysis generated 3 components which account for approximately $72 \%$ of the total cumulative variance in agricultural vulnerability.

- In component $1,26 \%$ of variation is explained by 3 variables, namely, $\%$ of gross area irrigated, cropping intensity and \% of commercial crops to TCA. 
Table 8 Rotated component matrix

\begin{tabular}{|c|c|c|c|}
\hline \multirow[t]{2}{*}{ Agricultural indicators } & \multicolumn{3}{|c|}{ Component } \\
\hline & 1 & 2 & 3 \\
\hline $\begin{array}{l}\% \text { of net sown area to total geographical area (TGA) ( } 3 \text { years } \\
\text { average) }\end{array}$ & 0.190 & 0.836 & 0.085 \\
\hline Cropping intensity & 0.754 & 0.269 & 0.089 \\
\hline $\begin{array}{l}\% \text { of gross irrigated area to total cropped area (TCA) ( } 3 \text { years } \\
\text { average) }\end{array}$ & 0.685 & 0.369 & 0.220 \\
\hline$\%$ of fallow land to TGA ( 3 years average) & 0.286 & 0.237 & 0.779 \\
\hline$\%$ of area under commercial crops to TCA & 0.793 & 0.284 & 0.415 \\
\hline No. of tractors/1000 ha area sown & 0.007 & 0.772 & 0.103 \\
\hline Agricultural cooperative societies/lakh population & 0.172 & 0.140 & 0.850 \\
\hline
\end{tabular}

- In component 2, $24 \%$ of variation is explained by 2 variables, namely, $\%$ of NSA to total geographical area and number of tractors/1000 ha area sown.

- In component 3,22\% of variation is explained by 2 variables, i.e. \% of fallow land to total geographical area, and agricultural cooperative societies/lakh population.

\section{Socio-economic Vulnerability Index for the Districts of Karnataka}

For development of the socio-economic vulnerability index, 10 important indicators described in Table 3 were considered. As agriculture is a dominant livelihood activity, a few agricultural indicators have also been included in the development of this index.

In Table 7 rank 1 indicates maximum vulnerable district and vulnerability decreases with increasing rank. PCA shows that Yadgiri, Chitradurg, Raichur, Chamrajnagar and Chikkaballapura are the top five socio-economically vulnerable districts. Bangalore (U), Dakshin Kannada, Udupi, Dharwad and Uttara Kannada are the least socio-economically vulnerable districts of Karnataka. Figure 18 depicts the socio-economically vulnerable districts of Karnataka, with red and green coloured areas representing most and least vulnerable districts, respectively. Table 9 gives the details of significance of variables that explain variation in each component.

- The rotated factor analysis generated 3 components which account for approximately $67 \%$ of the total cumulative variance in socio-economic and livelihood vulnerability. 


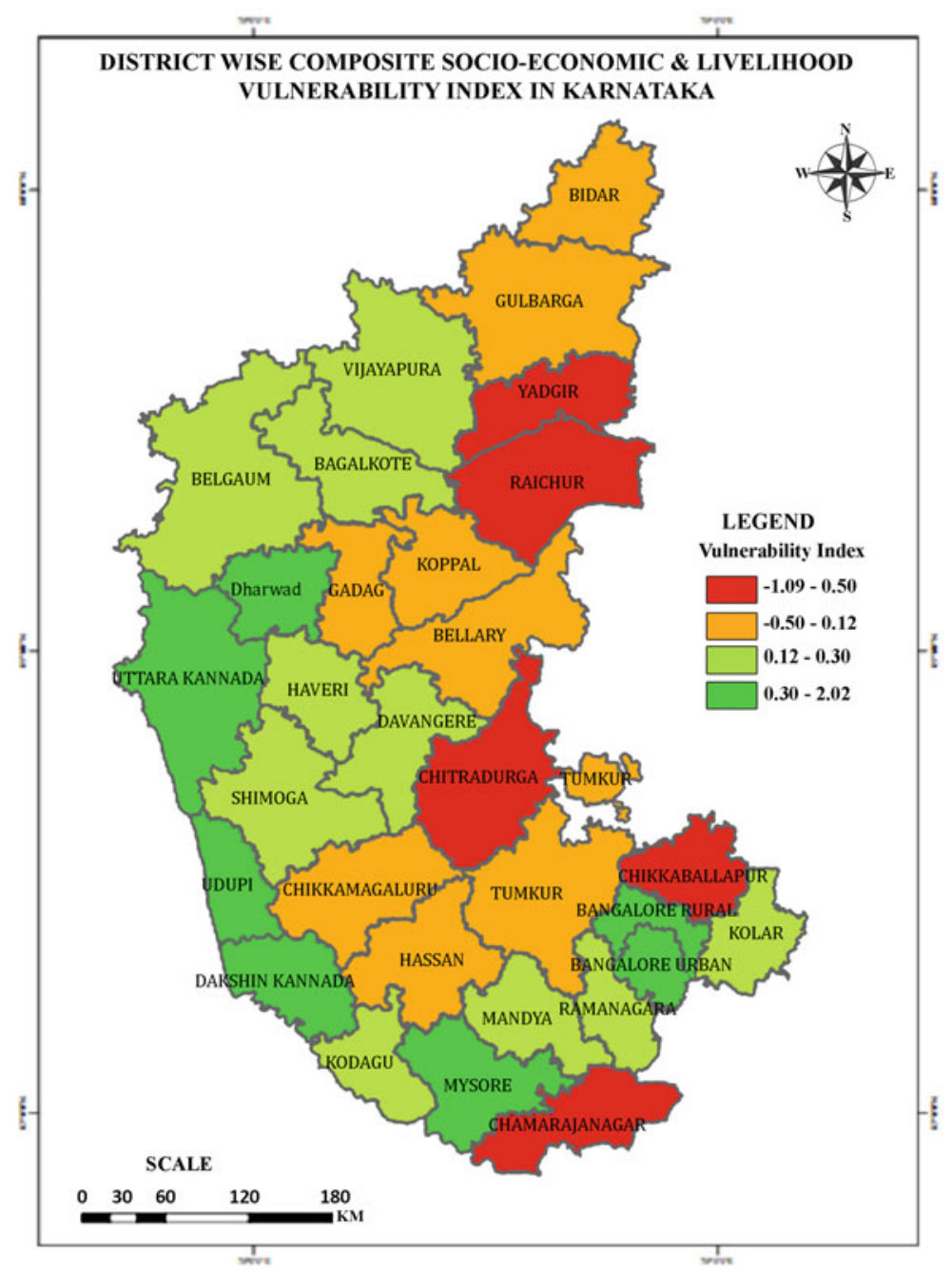

Fig. 18 Socio-economic vulnerability index. (Note Areas in red are the most socio-economically vulnerable districts and those in green are the least vulnerable districts of Karnataka)

- Factor 1 that accounts for the largest variance (about $31 \%$ ) includes population density, percentage of literacy rate, livestock unit/lakh population and per capita income.

- In component 2, $20 \%$ variation is explained by 3 variables, namely, percentage of SC and ST population, percentage of marginal land holders and total area under fruit crops.

- In factor 3,16\% of variation is explained by 3 variables, namely, percentage of non-workers, cropping intensity and percentage of irrigated area. 
Table 9 Rotated component matrix (a)

\begin{tabular}{l|l|l|l}
\hline Socio-economic indicator & \multicolumn{3}{l}{ Component } \\
\cline { 2 - 4 } & 1 & 2 & 3 \\
\hline Density of population & 0.825 & 0.040 & 0.076 \\
\hline \% SC and ST population & 0.467 & 0.529 & 0.404 \\
\hline Total literacy rate (\%) & 0.628 & 0.558 & 0.001 \\
\hline \% of marginal land holders & 0.172 & 0.802 & 0.229 \\
\hline \% of non-workers & 0.329 & 0.224 & 0.739 \\
\hline Livestock units per lakh population & 0.850 & 0.105 & 0.107 \\
\hline (3 years average) per capita income & 0.875 & 0.202 & 0.112 \\
\hline Cropping intensity & 0.142 & 0.302 & 0.668 \\
\hline \% gross irrigated area to total cropped area (3 years average) & 0.382 & 0.272 & 0.563 \\
\hline Total fruit crops area & 0.034 & 0.728 & 0.110 \\
\hline
\end{tabular}

\section{Discussion and Drivers of Vulnerability}

Karnataka state is one of the fastest growing economies in India. Agriculture in Karnataka is predominantly rainfed. In the present study, two vulnerability indices were developed at the district level of Karnataka state, i.e. agricultural vulnerability index and socio-economic vulnerability index, considering all the 30 districts of Karnataka for the analysis.

In order to derive these indices, a PCA was run on a data set of 10 carefully selected indicator variables to represent socio-economic vulnerability and 7 indicators for agricultural vulnerability across the districts of Karnataka. The PCA generated three components for each index that broadly represented the underlying themes of agriculture and socio-economic vulnerability present in the larger data set. The findings suggest

- Agricultural vulnerability

- Kolar, Ramanagara, Chikkaballapura and Bangalore (R) are the most agriculturally vulnerable districts of Karnataka.

- Belgaum, Haveri and Gadag are the least agriculturally vulnerable districts.

- Socio-economic and livelihood vulnerability

- Yadgiri, Chitradurg, Raichur, Chamrajnagar and Chikkaballapura districts are the most vulnerable among all districts of Karnataka.

- Bangalore (U), Dakshin Kannada, Udupi, Dharwad and Uttara Kannada are the least vulnerable districts of Karnataka.

The result of agricultural vulnerability index suggests indicators like cropping intensity, gross area irrigated and commercial crop area are the major drivers in 
determining the vulnerability of districts. The livelihood vulnerability index analysis suggests Yadgir, Chitradurg, Raichur, Chamrajnagar and Chikkaballapura are the most vulnerable districts in Karnataka. The livelihood index depicts indicators like per capita income, population density, percentage of literacy rate and livestock units/lakh population, which are the major drivers and contribute to the overall livelihood vulnerability of districts.

\section{References}

Adger, W. N., Brooks, N., Bentham, G., Agnew, M., \& Eriksen, S. (2004). New Indicators of Vulnerability and Adaptive Capacity. Technical Report 7, Tyndall Centre for Climate Change Research. Norwich UK.

Allen, K. (2003). Vulnerability reduction and the community-based approach. In Pelling (Ed.), Natural disasters and development in a globalizing world (pp. 170-184). London, UK: Routledge.

Fussel, H.-M. (2007). Vulnerability: A generally applicable conceptual framework for climate change research. Global Environmental Change, 17, 155-167.

Government of Karnataka. (2005). Human Development Report, Karnataka. Bangalore, India: Government of Karnataka.

Hiremath, D., \& Shiyani, R. L. (2013). Analysis of vulnerability indices in various agro-climatic zones of Gujarat. Indian Journal of Agricultural Economies, 68(1), 122

ICRISAT. (2009). Quantitative assessment of vulnerability to climate change. (http://www.icrisat. org/what-we-do/impi/training-cc/october-2-32009/vulnerability-analysis-manual.pdf. Accessed Aug 2013).

IISc. (2013). Environmental benefits and vulnerability reduction through Mahatma Gandhi National Rural Employment Guarantee Scheme. Synthesis Report 2013. Bangalore, India: Indian Institute of Science.

IPCC. (1996). Climate change 1995 second assessment report of the intergovernmental panel on climate change. Geneva: Switzerland.

IPCC. (2001). Climate change 2001: The scientific basis. Contribution of Working Group I to the Third Assessment Report of the Intergovernmental Panel on Climate Change. Cambridge, UK: Cambridge University Press.

IPCC. (2007). IPCC Fourth Assessment Report: Climate Change 2007 (AR4). Cambridge, UK: Cambridge University Press.

Karade, J. (2008). Development of Scheduled Castes and Scheduled Tribes in India. UK: Cambridge School of Publishing.

Khan, F. A., \& Salman, A. (2012). A simple human vulnerability index to climate change hazards for Pakistan. International Journal of Disaster Risk Science, 3(3), 163-176.

Nicholls, R. J., Hoozemans, F. M. J., \& Marchand, M. (1999). Increasing flood risk and wetland losses due to global sea-level rise: Regional and global analyses. Global Environmental Change, 9, S69-S87.

Senbeta, A. F. (2009). Climate change impact on livelihood, vulnerability and coping mechanisms: A case study of West Arid Zone, Ethiopia. MSc thesis submitted to Lund University Masters Program in Environmental Studies and Sustainability Science (LUMES), Lund, Sweden.

Smith, L. I. (2002). A tutorial on principal component analysis. In H. Anton (Ed.), Elementary linear algebra 5e (Vol. 2012). New York: Willey. ISBN, 0-471-852236.

Stern, N., Peters, S., Bakhshi, V., Bowen, A., Cameron, C., Catovsky, S., et al. (2006). Stern review: The economics of climate change. New York: OUP. 
Swain, M., \& Swain, M. (2011). Vulnerability to agricultural drought in Western Orissa: A case study of representative blocks. Agricultural Economics Research Review, 24, 47-56.

Watson, R. T., Zinyoera, M. C., \& Moss, R. H. (1996). The regional impact of climate change: An assessment of vulnerability. A Special Report of IPCC Working Group II. Cambridge, UK: Cambridge University Press. 